\section{Nauplius}

The Journal of The

Brazilian Crustacean Society

\author{
e-ISSN 2358-2936 \\ www.scielo.br/nau \\ www.crustacea.org.br
}

\title{
A compilation of longevity data in decapod crustaceans
}

\author{
Günter Vogt ${ }^{1}$ (1) orcid. org/0000-0002-5632-2477 \\ 1 Faculty of Biosciences, University of Heidelberg, Im Neuenheimer Feld 234, 69120 \\ Heidelberg, Germany \\ ZOOBANK: http://zoobank.org/urn:lsid:zoobank.org:pub:2A8C90D1-DA78-46AC- \\ 8C7E-85A4172EEF75
}

\section{Abstract}

Longevity information was collected from 219 literature sources for 244 decapod crustaceans, representing $1.7 \%$ of species, $4.8 \%$ of genera and $30 \%$ of families. Reliable methods of age determination (laboratory rearing, markrecapture method, growth models, lipofuscin method) revealed longevities from 0.1 to 72 years, corresponding to a 700 -fold difference between the shortest and longest lived species. The mean longevity of the species included in this article is 7.1 years $(\mathrm{SD}=10.18 ; \mathrm{CV}=142.9 \%) ; 61.1 \%$ of the species live less than 5 years, $29.5 \%$ live between 5 and 20 years, and 9.4\% live longer than 20 years. The basal Dendrobranchiata have a mean longevity of only 2.1 years whereas the Achelata have a mean longevity of 27.2 years. The oldest decapod aged with a direct method is a hermit crab that was reared in captivity for more than 42 years. The particularly long-lived species belong to different families of the infraorders Achelata, Astacidea, Anomura and Brachyura. Average longevity is highest in semiterrestrial and terrestrial habitats ( 13.0 years), followed by freshwater ( 7.2 years) and marine and brackish waters (6.0 years). The deep sea, polar waters, freshwater caves and terrestrial environments apparently promote the evolution of high life spans.

\section{KEYWORDS}

Decapoda, life span, environment, taxonomy, evolution.

CORRESPONDING AUTHOR

Günter Vogt

gunter.vogt@web.de

SUBMITTED 02 April 2019

ACCEPTED 06 July 2019

PUBLISHED 16 September 2019

DOI 10.1590/2358-2936e2019011

\section{(cc) BY}

All content of the journal, except where identified, is licensed under a Creative Commons attribution-type BY.

Nauplius, 27: e2019011 
Brink, 2016), brachyuran crabs (McLay, 2015), cave dwelling decapods (Venarsky et al., 2012), and crustaceans (Vogt, 2018). In the present article I have compiled and updated all reliable longevity data of decapods that I could find in original studies, review papers and species profiles provided by experienced carcinologists. In addition, I have compared longevities between the higher taxa of the Decapoda and between marine, freshwater and terrestrial environments.

\section{Ageing techniques and their advantages and disadvantages}

The longevity data compiled in this paper were obtained with different ageing techniques like growth models, the lipofuscin method, the mark and recapture method, and rearing in captivity. Growth models based on size-frequency and life history data were predominant. Sometimes, life spans were directly estimated from size-frequency and life history data without applying growth models. An alternative indirect ageing method was quantification of the age pigment lipofuscin. The direct methods applied were the mark-recapture method and rearing in captivity.

Rearing in captivity from hatching to death is the most exact ageing technique. However, life span data obtained with this approach are mainly available for relatively short-lived aquaculture, laboratory and pet species. This method underestimates longevity in the wild if the culture conditions are inadequate. On the other hand, it can considerably overestimate natural longevity because protection from adverse environmental conditions, predators and diseases can greatly expand life span. Thus, rearing under optimal conditions reflects the upper possible age limits of the species.

The mark and recapture method is presently the only direct ageing technique applied in the wild. In order to ensure life-long retention of the mark, the tags have to be placed underneath the cuticle. Otherwise, they are lost during moulting. There are several internal markers available for decapods, among them passive integrated transponders (microchips), coded microwire tags, visible implant alphanumeric tags and visible implant elastomeres (Hartnoll, 2001; Davis et al., 2004; Buřič et al., 2008). Further details on markrecapture methods are found in Hartnoll (2001), Vogt (2012) and Kilada and Driscoll (2017). In practice, the mark-recapture method was mostly used to estimate growth increment per year, which was then used in growth models. There are only few cases where marked specimens were recaptured after more than a decade. For example, a Procambarus erythrops crayfish was recaptured in Sim's Sink cave, Florida, 16 years after marking (Streever, 1996).

The most widespread ageing method used in wild populations is the analysis of length-frequency distributions and reproduction parameters, often combined with growth models. Size frequency analysis depends on the identification of modes in the distribution, which can be equated with recruitment cohorts or year classes. The raw data are first grouped into length groups and then converted to age groups. Growth models such as the von Bertalanffy equation help to estimate longevity from length frequency and life history data. Further details are found in Hartnoll (2001) and Jennings et al. (2001). Size frequency analysis gives reliable information for short-lived species with well-defined annual reproduction periods. The approach becomes increasingly unreliable the longer a species lives because slowly growing specimens of older age may group together with fast growing specimens of younger age. Since these effects increase with age, size-frequency based growth models are imprecise in long-lived species (Sheehy et al., 1999; Hartnoll, 2001). Moreover, the von Bertalanffy growth model assumes that an organism reaches a maximum size and approaches this size asymptotically. This assumption holds for the determinately growing decapods like the snow crab Chionoecetes opilio, which stops growing after a terminal moult but continues to live for several years (Ernst et al., 2005). However, most decapods are indeterminate growers and have no fixed growth limit.

The lipofuscin method is based on the continuous, life-long deposition of lipofuscin in persistent cell types. Lipofuscin is a fluorescent, yellow-brown aggregate consisting of oxidized protein and lipid clusters (Jung et al., 2007). It originates from lysosomal degradation of cytosolic proteasome-protein complexes and damaged cell organelles. Lipofuscin is insoluble, resists enzymatic degradation and is deposited in residual bodies within the cells. The neurons and neuroglia of some brain areas of decapods obviously persist throughout life and accumulate lipofuscin with age, providing ideal targets for lipofuscin-based age determination (Sheehy, 1992). The lipofuscin content is usually quantified 
by measurement of the lipofuscin area in histological sections and, less reliably, by spectrofluorometric analysis. The lipofuscin content is a marker of the physiological age rather than the chronological age, and therefore, calibration is required with specimens of known age and for each environment (Sheehy et al., 1995b; Maxwell et al., 2007). In long-lived species, the lipofuscin method is apparently superior to size or weight based ageing techniques (Belchier et al., 1998).

Leland et al. (2011) and Kilada et al. (2012) suggested using cuticular growth bands of stomach ossicles and the growing edge of the eyestalks for age determination. The interpretation of cuticle bands in the ossicles as annual age marker is based on the idea that parts of the gastric mill are retained through the moult and accumulate a continuous record of age. Analyses in several species seemed to support this idea (Kilada and Driscoll, 2017; Gnanalingam et al., 2019). However, Sheridan and O'Connor (2018) and Becker et al. (2018) revealed in several species that the zygocardiac ossicles in question are shed during moulting and wondered how the age information could be transferred to the new cuticle. Because of this unsettled controvery, I have not included growth band data in this paper.

\section{ResUltS}

Table 1 includes 282 longevity data for 244 species. These data are heterogeneous because they were obtained with different ageing methods: 108 data come from growth models (mainly von Bertalanffy equations), 61 from the analysis of size-frequency and life history data, 19 from the mark and recapture method, 20 from rearing in captivity, 9 from the lipofuscin method, 2 from shell radiometry, 62 from review articles, book chapters and the discussion sections of papers, and 33 from species profiles compiled by experienced carcinologists (some papers have used more than one ageing approach). Table 1 lists the highest longevities given by the authors. These are either minimum expected life spans, maximum life spans estimated by growth models, or recorded ages of the oldest individuals. The list represents $1.7 \%$ of the 14,335 decapod species, $4.8 \%$ of the genera, $30 \%$ of the families and $63.6 \%$ of the sub-/infraorders.

Mean longevity of the 244 decapod species is 7.12 years with $4.1 \%$ of the species living less than 1 year,
$57.0 \%$ living from $1-4.9$ years, $18.4 \%$ from 5-9.9 years, $11.1 \%$ from $10-19.9$ years and $9.4 \%$ living beyond 20 years (Fig. 1). The oldest decapod in captivity is a 42-year old hermit crab (Coenobita clypeatus). This specimen was purchased by Carol Ann Ormes in summer 1976 and kept since then as a pet (Atlas Obscura, 2019). It was still alive in December 2018 (NBC2 News, 2018). The oldest marked decapod ever recaptured is a caridean freshwater shrimp (Xiphocaris elongata) from a headwater stream in Puerto Rico. It was recaptured after 18 years (Cross et al., 2008). The highest age determined by the lipofuscin method was $72 \pm 9$ years for a female of the European lobster, Hommarus gammarus, from the Yorkshire fishery in U.K. (Sheehy et al., 1999). The maximum age estimated by growth models was 70-100 years for females and males of coconut crab, Birgus latro, on Christmas island (Drew et al., 2013). The highest age ever estimated by growth models was 176 years in the cave-dwelling crayfish Orconectes australis (cf. Cooper, 1975). However, reinvestigation of new populations and Cooper's data with refined growth models revealed a longevity of 22 years for this species, with only a small proportion of individuals exceeding this age (Venarsky et al., 2012).

\section{Longevity differences between and within higher taxa}

Longevity varies markedly between sub-/infraorders (Table 2). The plesiomorphic Dendrobrachiata have average longevities of 2.1 years. The average lifespan of the derived Pleocyemata, which include all other infraorders, is 7.8 years. Caridea live on average for 4.2 years, Brachyura for 5.6 years, Astacidea for 11.0 years, Anomura for 11.4 years and Achelata for 27.2 years (Table 2). For the Gebiidea I have found only one reliable value of 4 years, and for the Axiidea, Polychelida and Glypheidea data are apparently lacking. Kornienko (2013) estimated the longevity of the Gebiidea and Axiidea to 2-5 years but mentioned that some workers have estimated their maximum life span to 10 years and more.

Longevity can markedly differ among members of the same higher taxon. Longevity varies from 0.1-9 years $(\mathrm{CV}=75.6 \%)$ in the Dendrobranchiata, 0.5-18 years $(\mathrm{CV}=96.7 \%)$ in the Caridea, $0.7-30$ years $(\mathrm{CV}=102.9 \%)$ in the Brachyura, 0.7-70 years $(\mathrm{CV}=161.2 \%)$ in the Anomura, $1.5-72$ years 


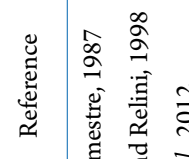

$\stackrel{\text { ते }}{\overrightarrow{0}}$

:

ㅇํㄹ

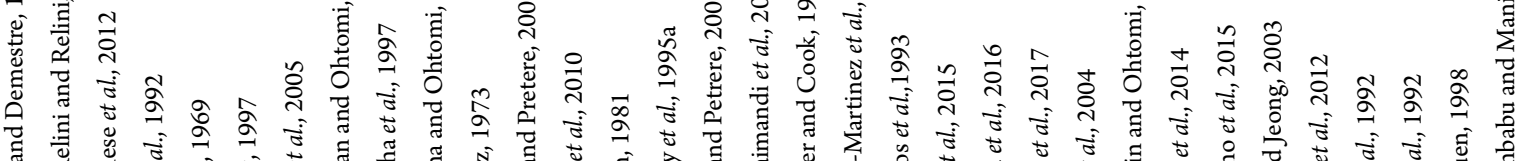

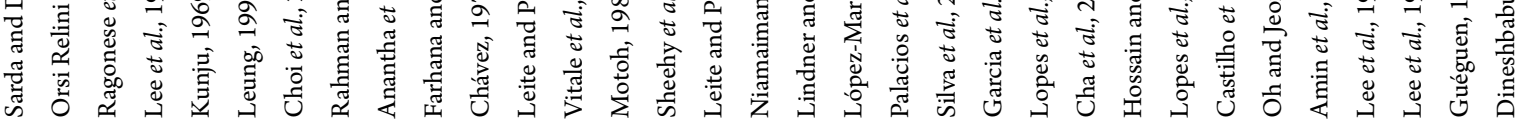

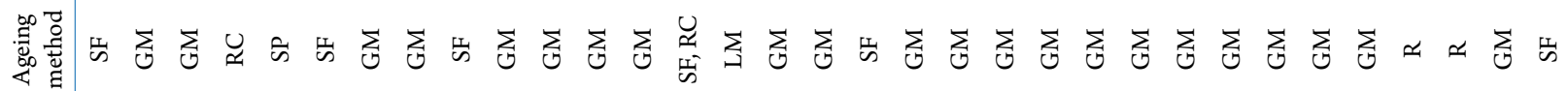

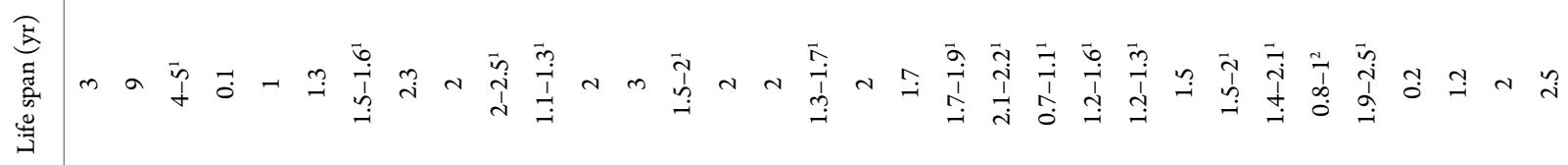

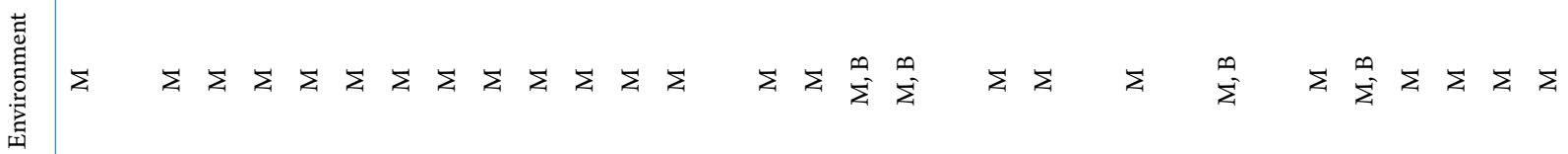

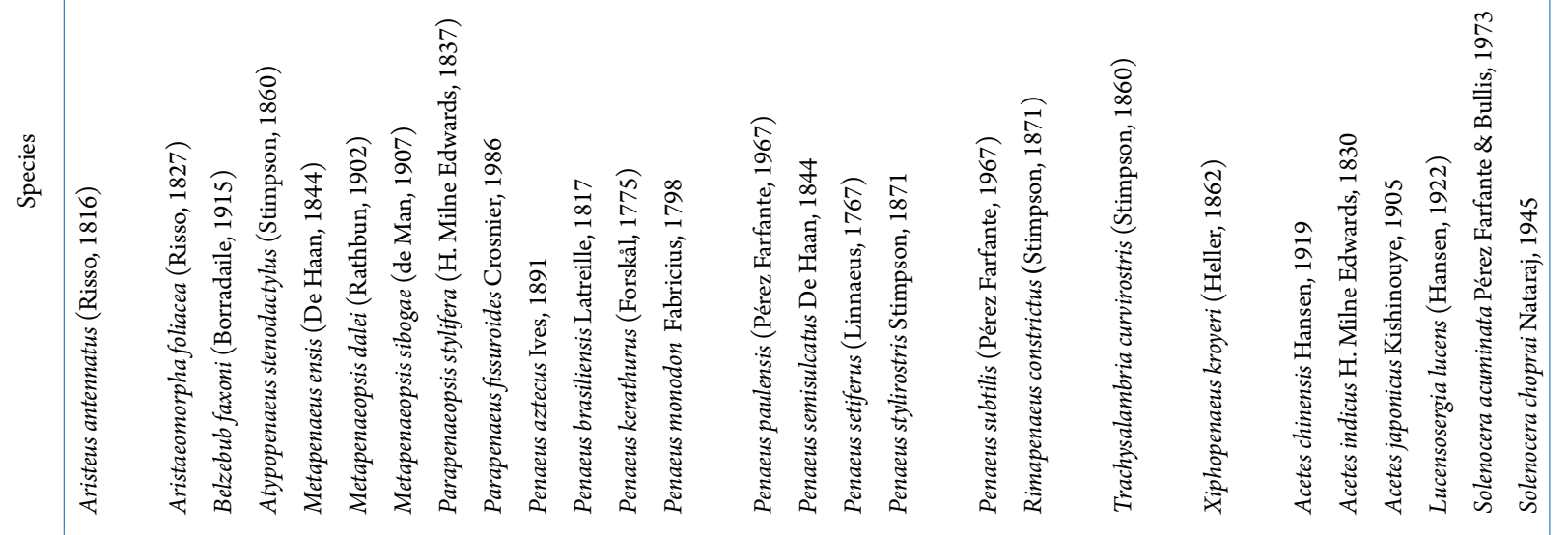

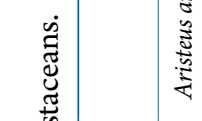

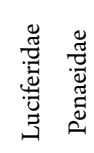

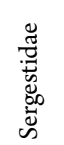

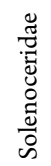




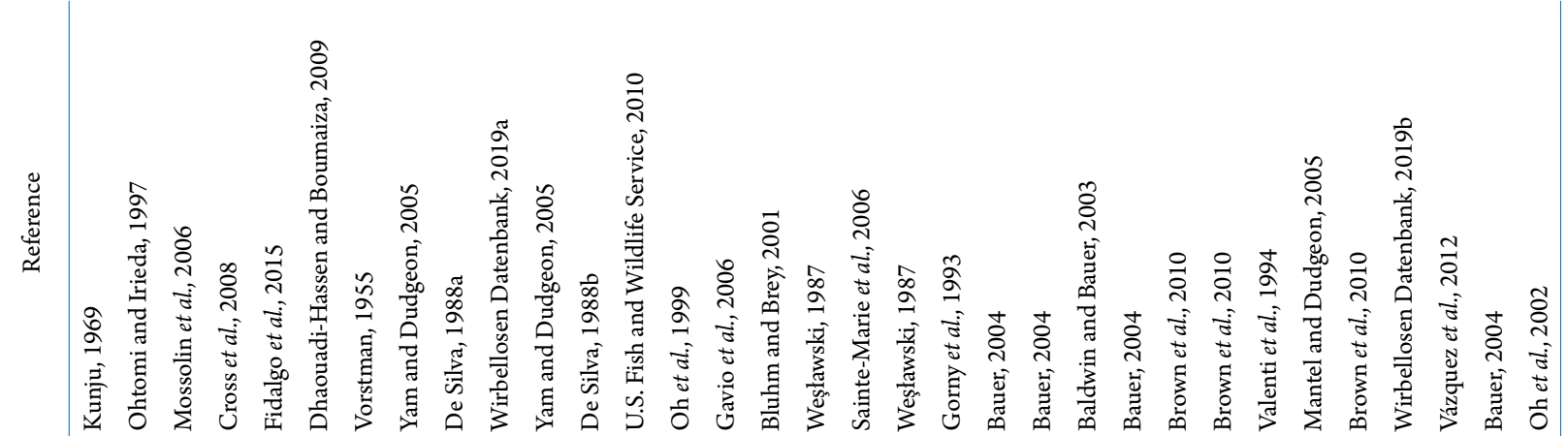

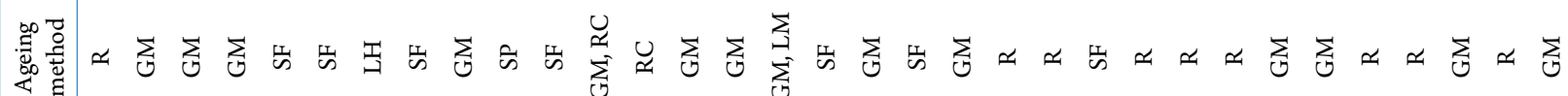

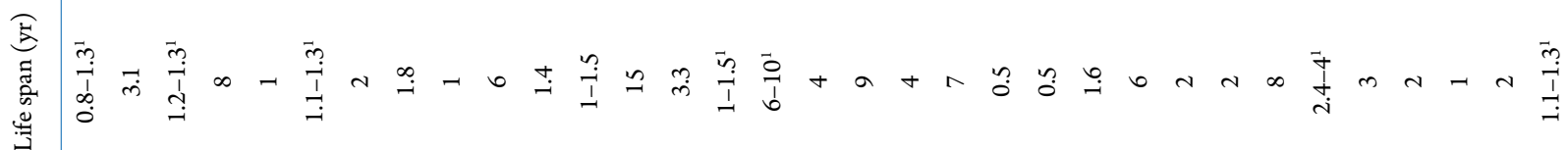

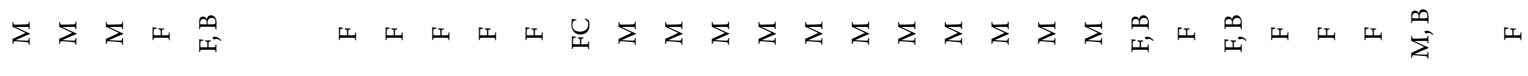
臭

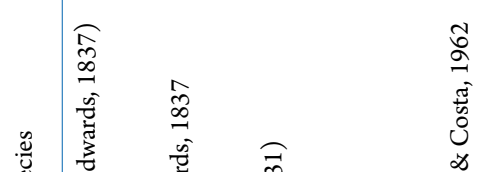

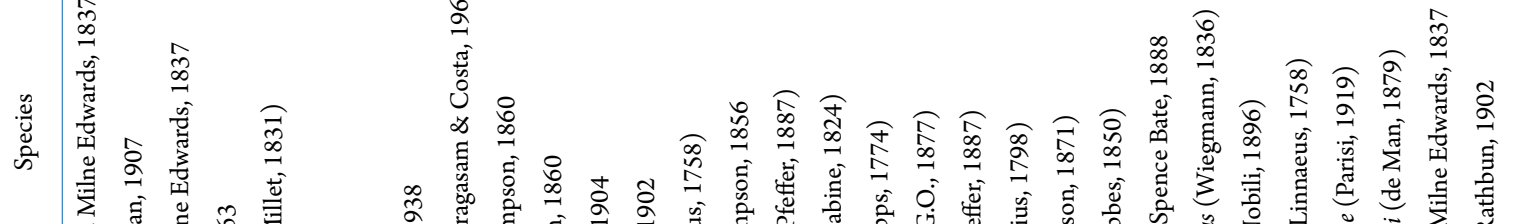

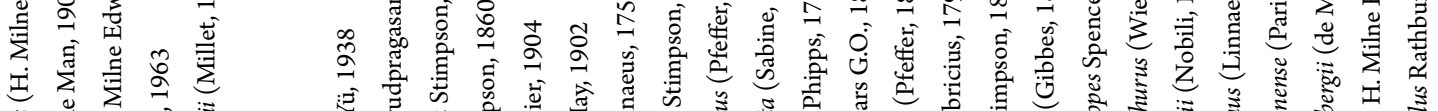

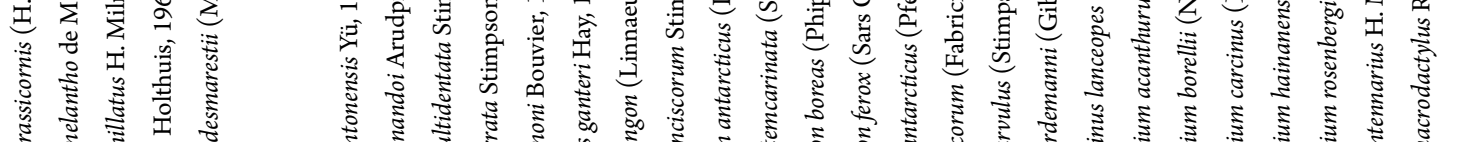

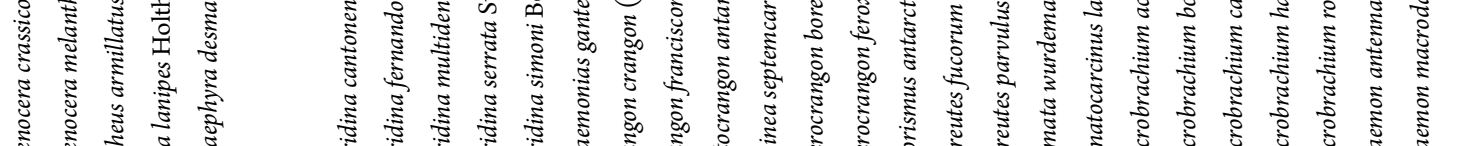

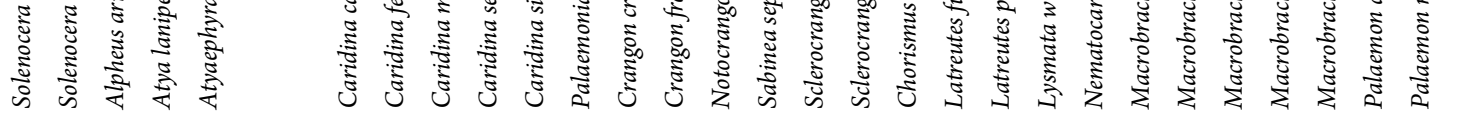

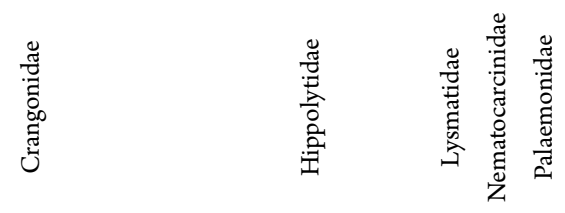




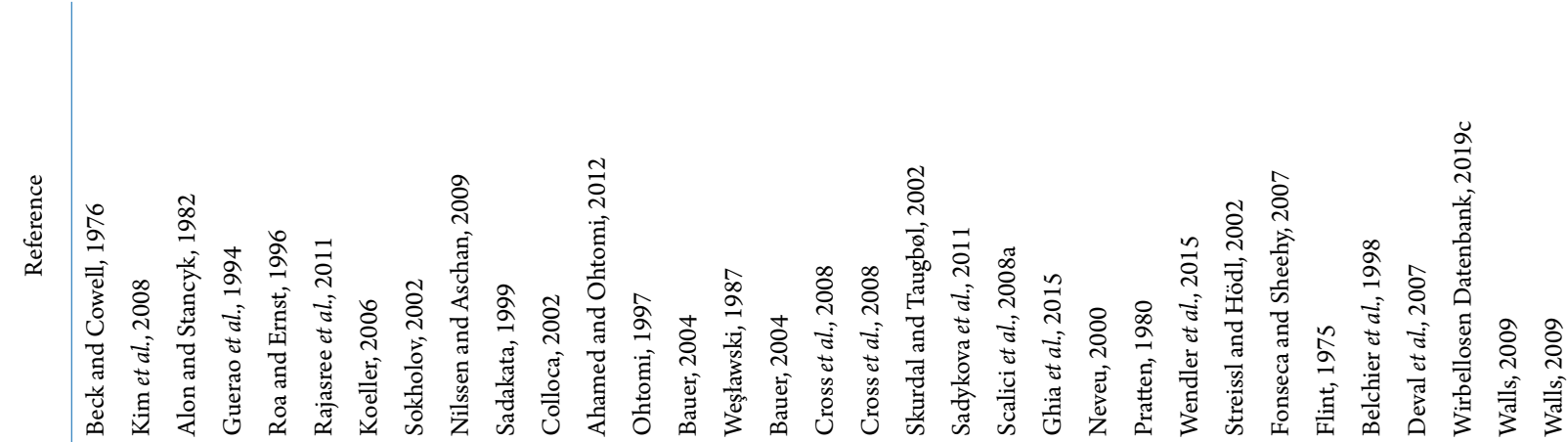

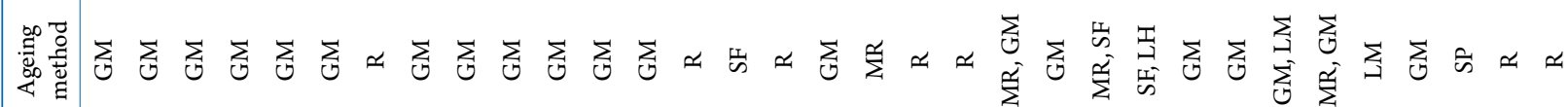

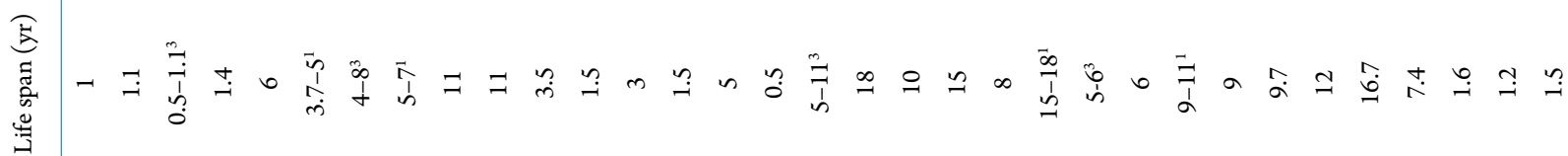

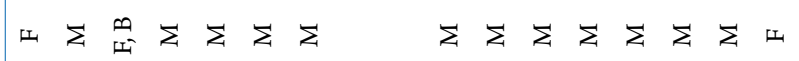

窇

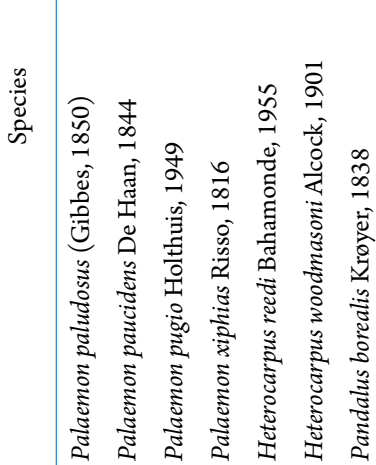
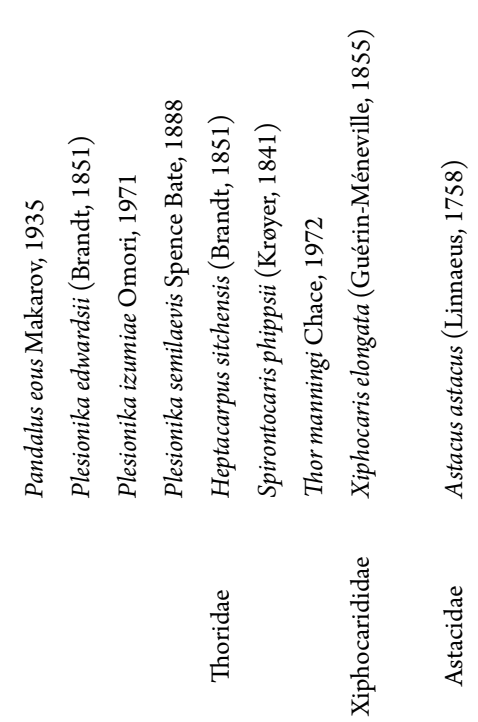

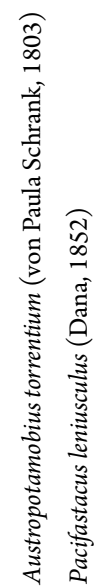

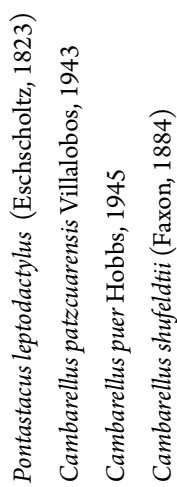

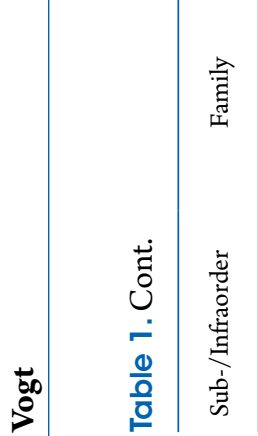
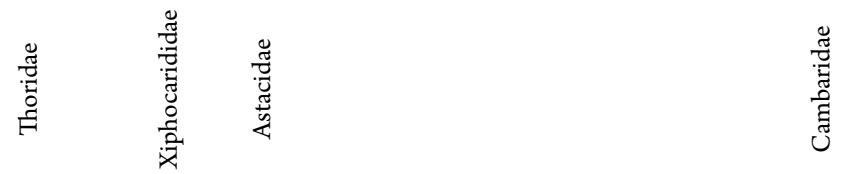

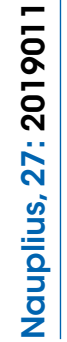




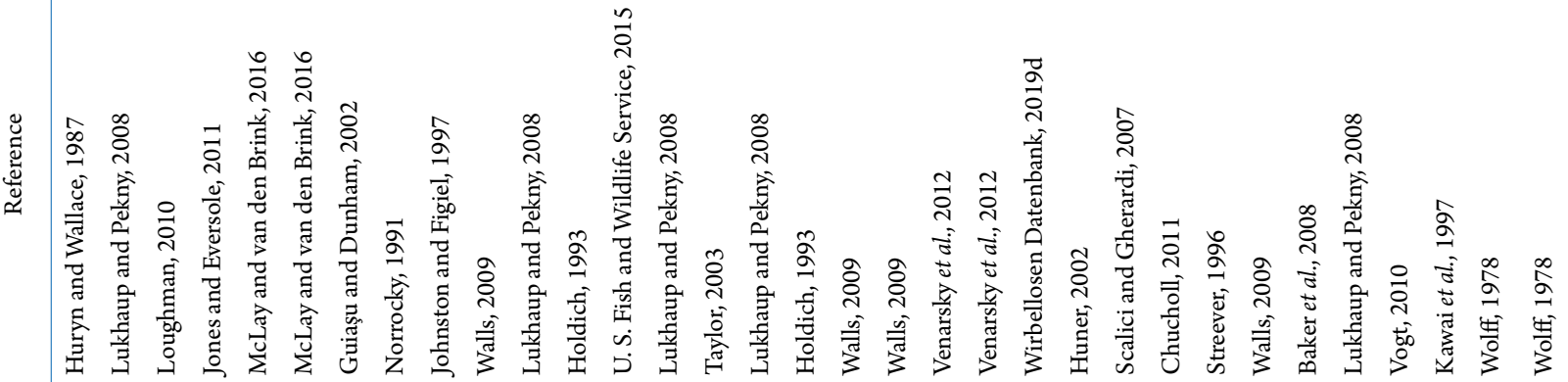

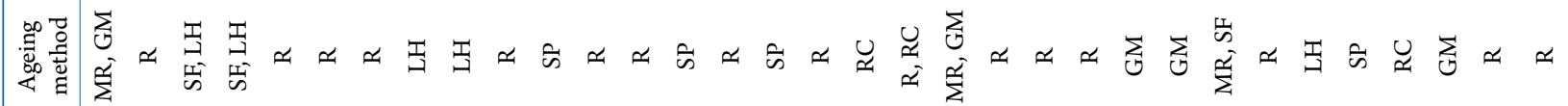

焉

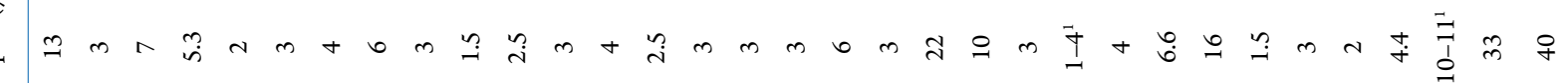

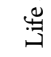

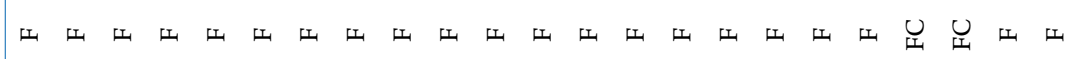

品山山山山

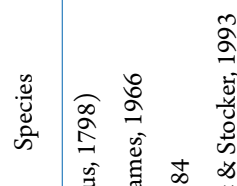

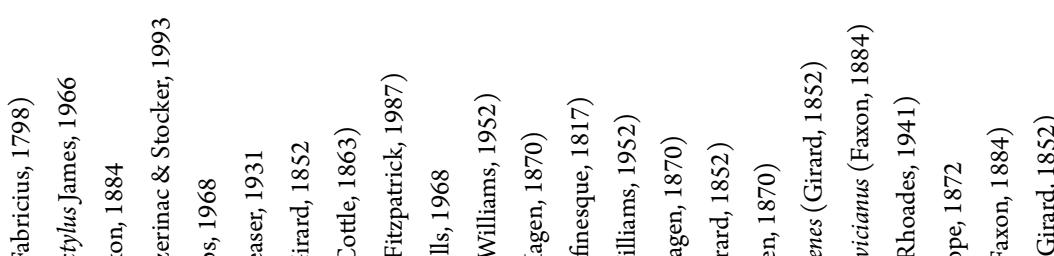

$\underset{\substack{f \\ \infty}}{\stackrel{f}{\infty}}$

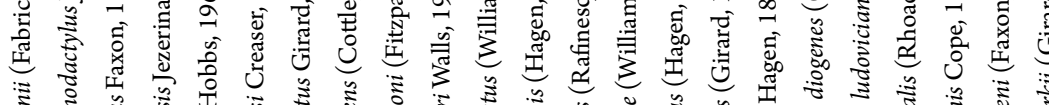

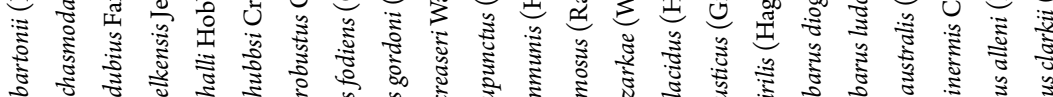

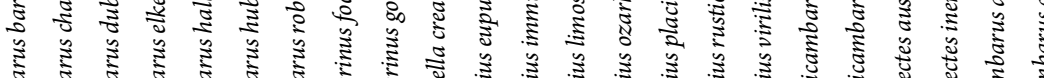

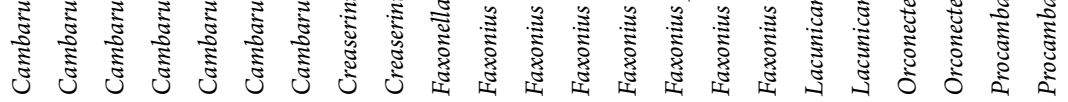

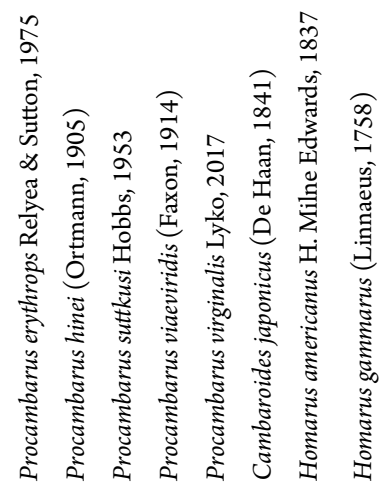

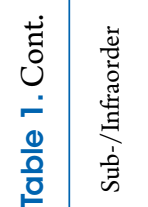




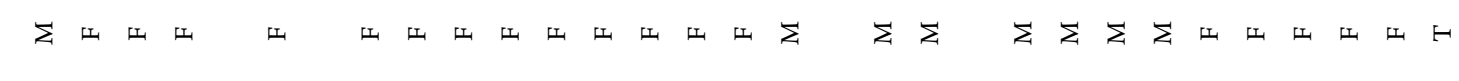
舫

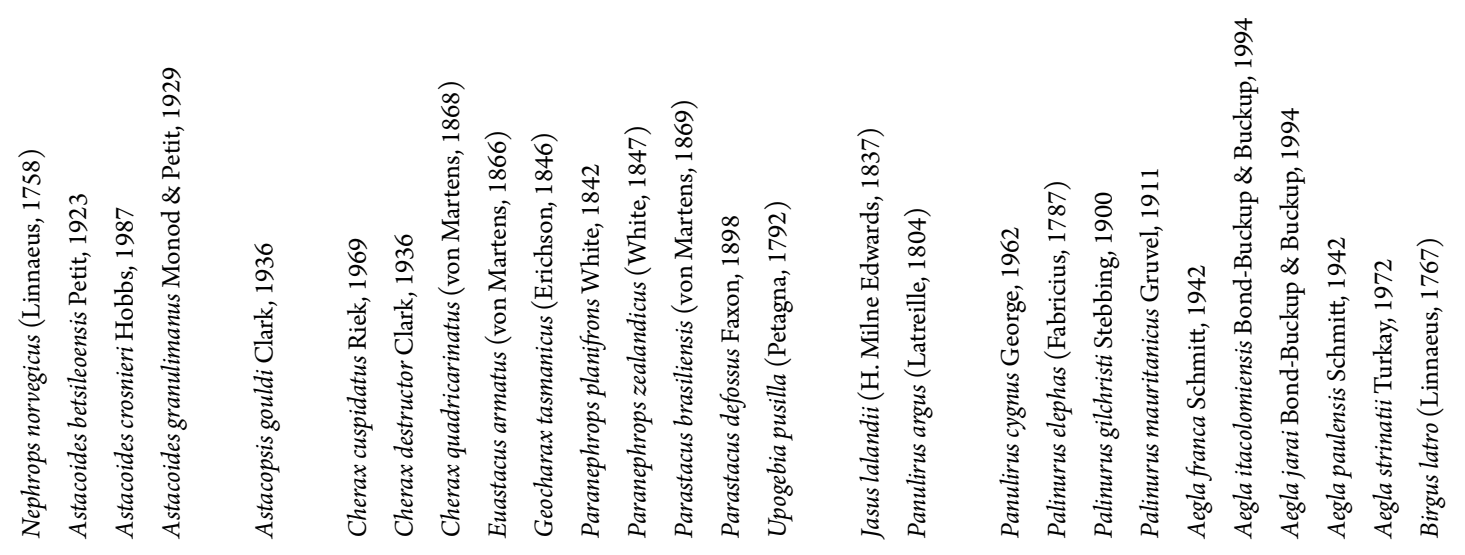




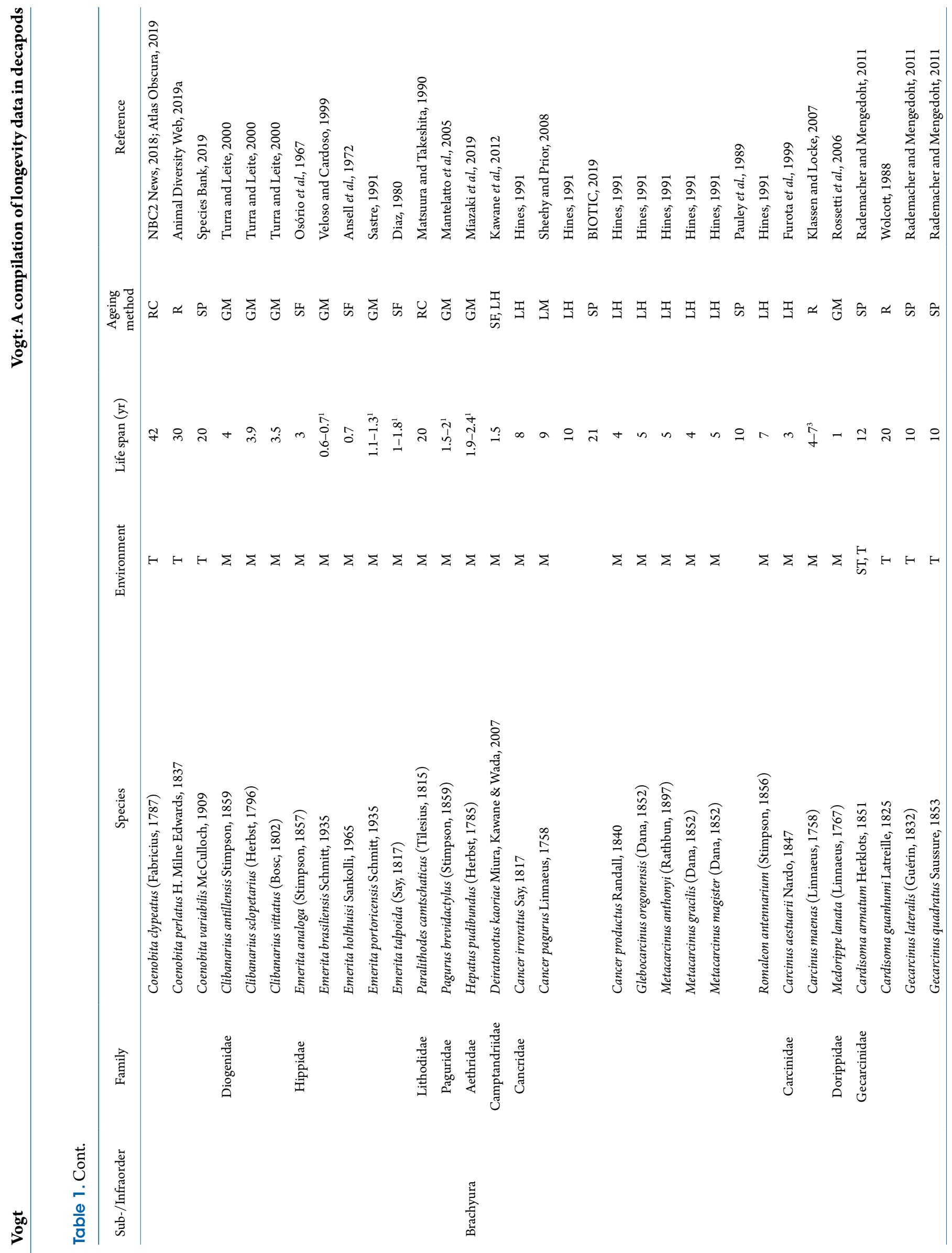




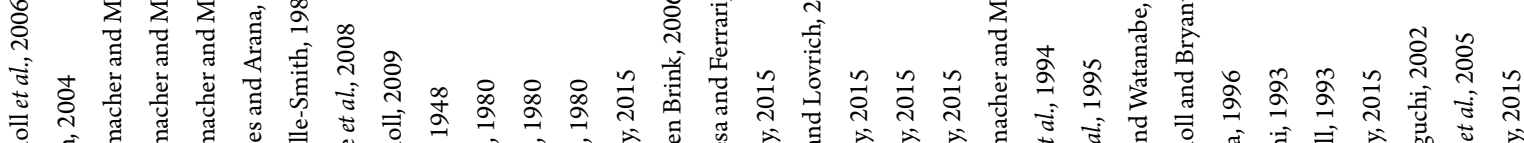

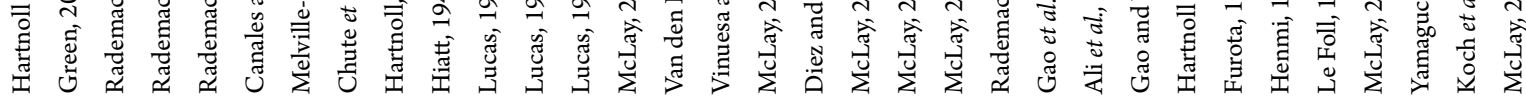

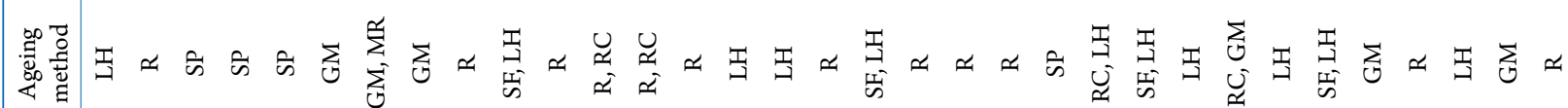

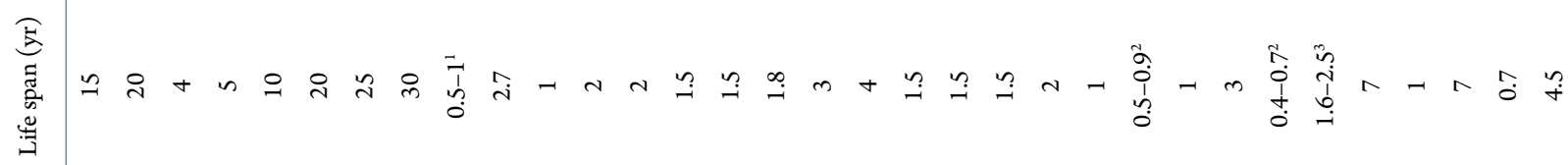

HH山山 山 舀

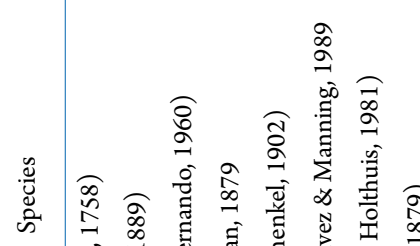

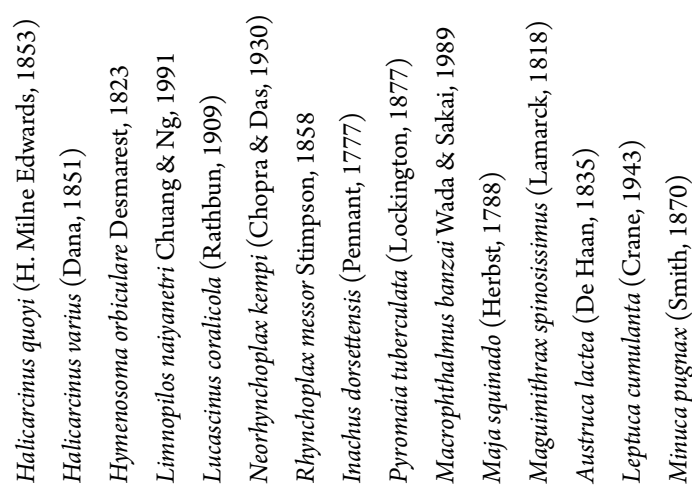

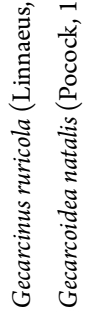

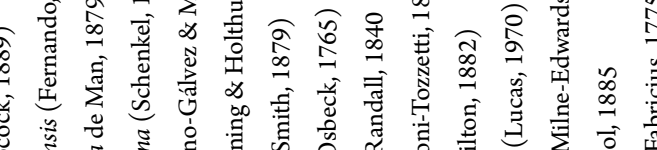

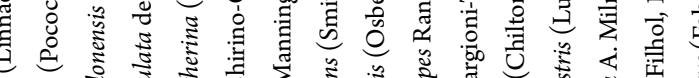

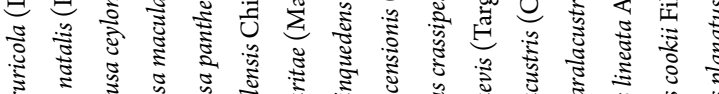

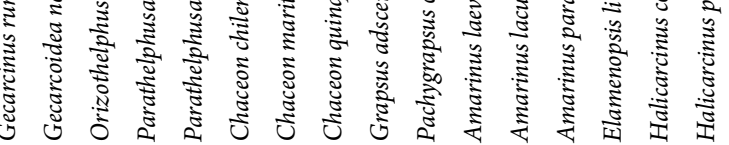
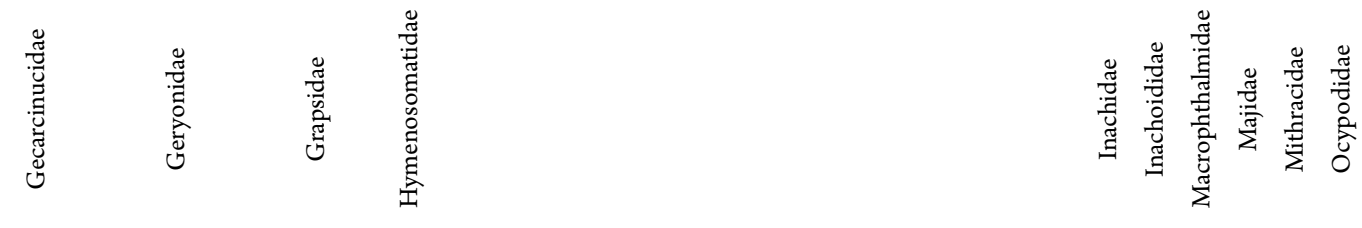


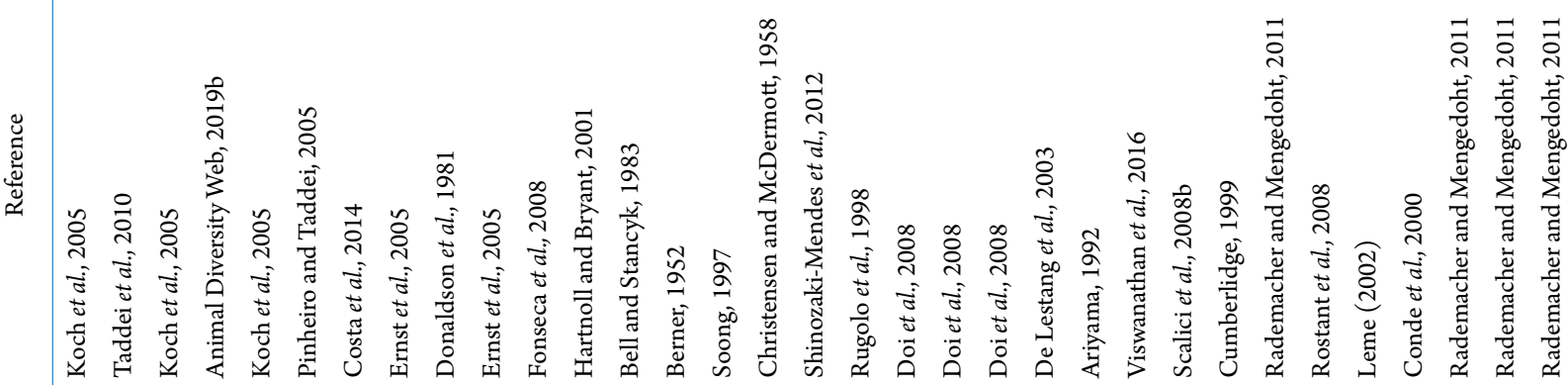

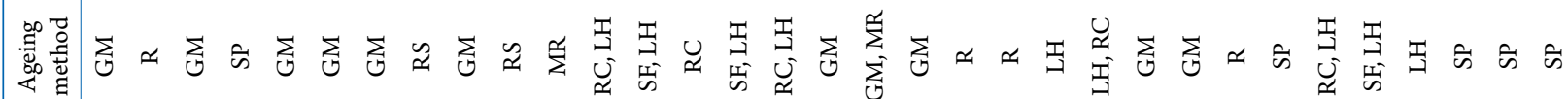

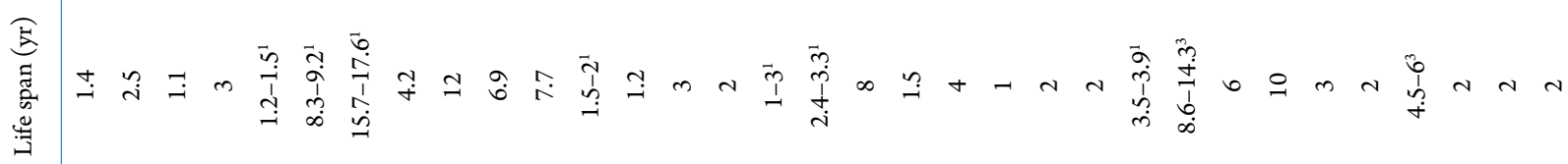

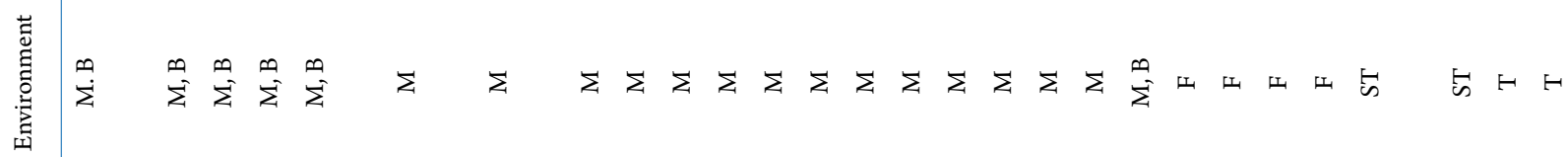

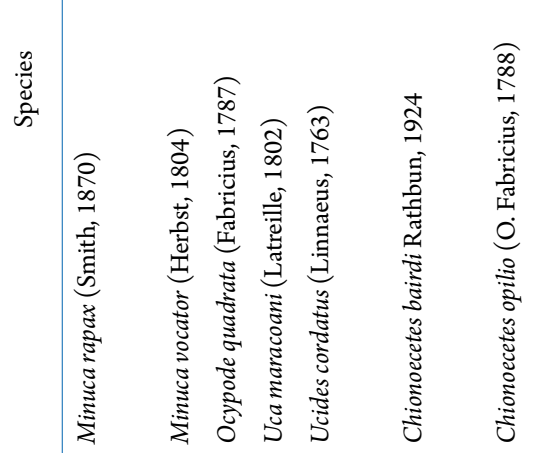

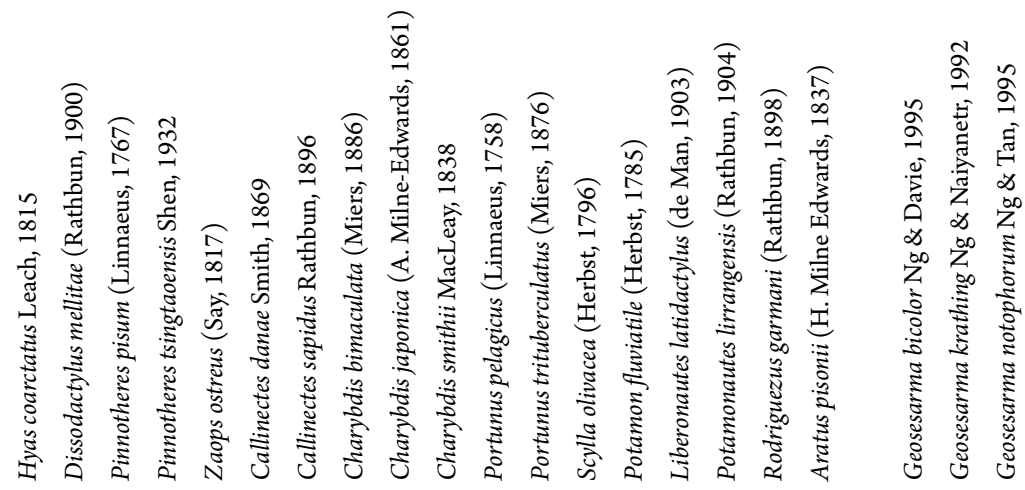

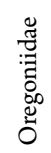

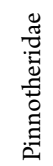

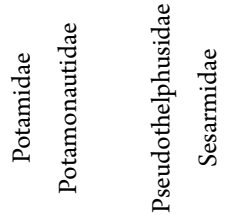




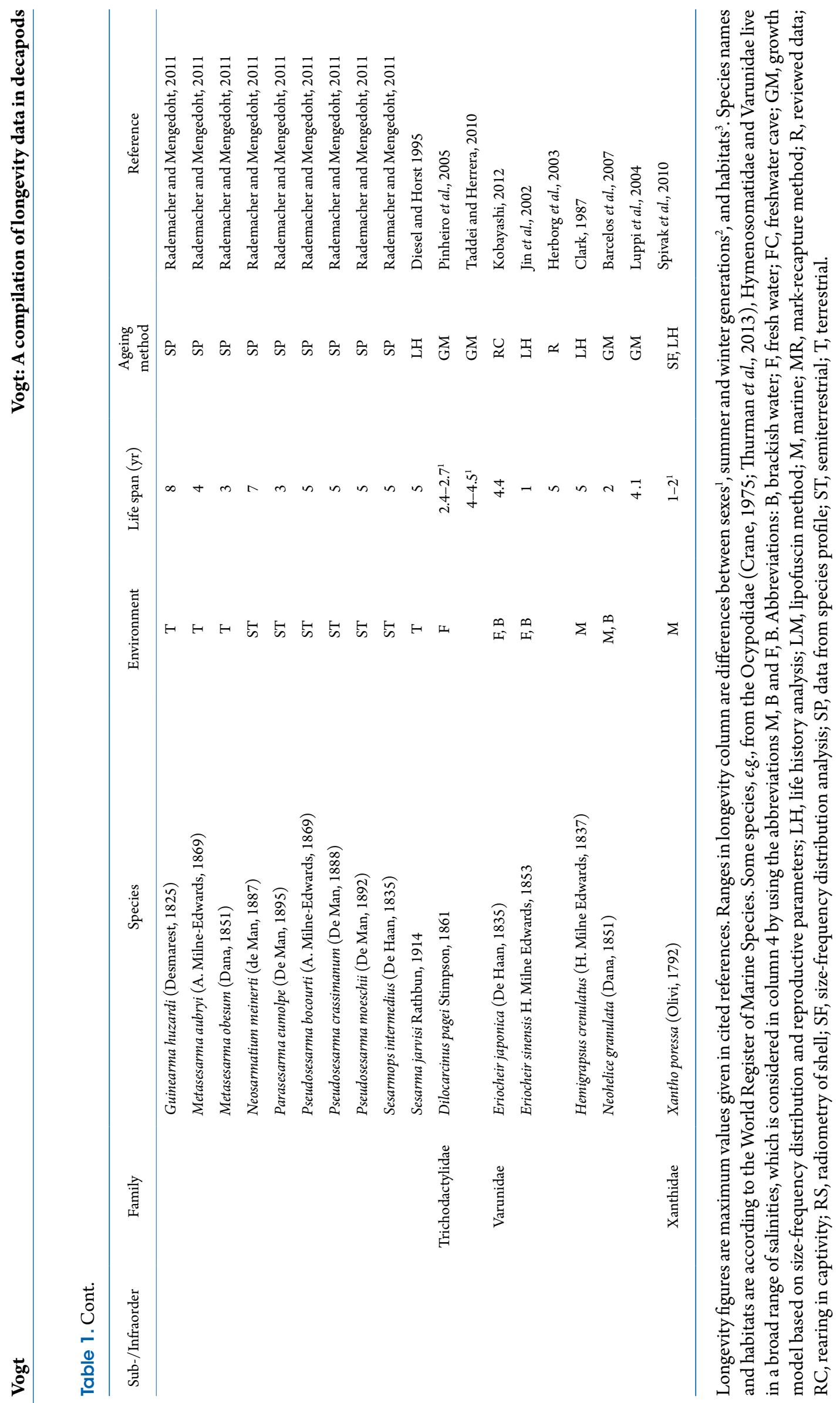


Table 2. Comparison of longevities between higher taxa.

\begin{tabular}{|c|c|c|c|}
\hline & No. of species with longevity data & $\begin{array}{l}\text { Longevity range } \\
(\mathrm{yr})^{*}\end{array}$ & $\begin{array}{c}\text { Mean }(y r) \pm S D \\
\text { and CV }(\%)\end{array}$ \\
\hline Dendrobranchiata & 29 of 540 & $0.1-9$ & $2.13 \pm 1.61 ; 75.6$ \\
\hline Caridea & 43 of 3,268 & $0.5-18$ & $4.19 \pm 4.05 ; 96.7$ \\
\hline Astacidea & 54 of 653 & $1.5-72$ & $11.00 \pm 13.80 ; 125.5$ \\
\hline Gebiidea & 1 of 192 & $4-4$ & $4.00 \pm 0.00 ; 0.0$ \\
\hline Achelata & 6 of 140 & $15-40$ & $27.17 \pm 8.56 ; 31.5$ \\
\hline Anomura & 19 of 2,451 & $0.7-70$ & $11.34 \pm 18.28 ; 161.2$ \\
\hline Brachyura & 92 of 6,559 & $0.7-30$ & $5.59 \pm 5.75 ; 102.9$ \\
\hline Decapoda & 244 of 14,335 & $0.1-72$ & $7.12 \pm 10.18 ; 142.9$ \\
\hline
\end{tabular}

* Based on reported maximum values of species. CV=coefficient of variation. No reliable data were found for the 69 Stenopodidea, 2 Glypheidea, 423 Axiidea and 38 Polychelida. Species numbers of decapod groups are from De Grave et al., 2009

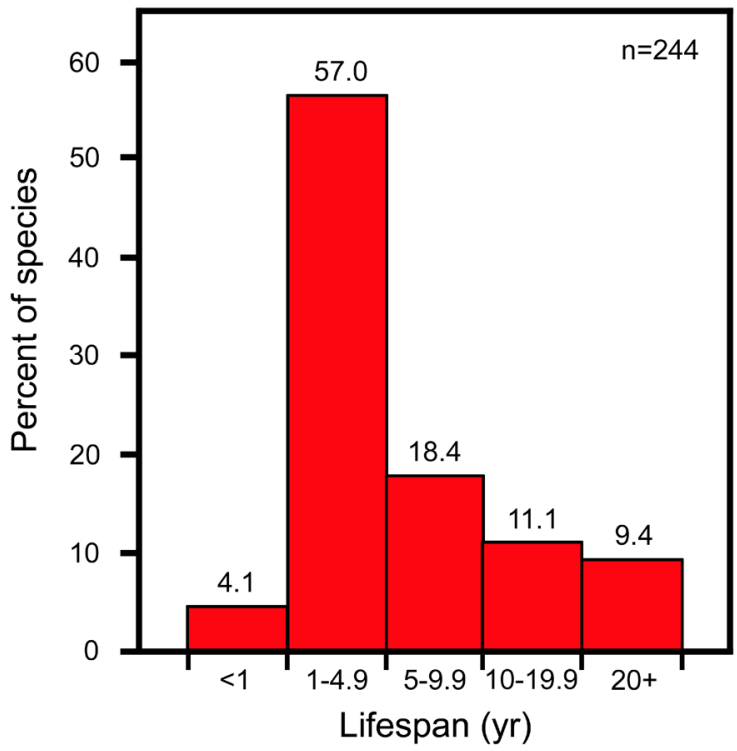

Figure 1. Longevity spectrum of the Decapoda. More than half of the 244 investigated species have life spans below 5 years. Approximately $20 \%$ of species live longer than 10 years and less than $10 \%$ reach ages above 20 years.

$(\mathrm{CV}=125.5 \%)$ in the Astacidea, and $15-40$ years $(\mathrm{CV}=31.5 \%)$ in the Achelata (Table 2). There are also marked differences within the same family or genus. Examples are the Cambaridae with life spans of 1.2-22 years and the genus Procambarus with life spans of 1.5-16 years (Table 1 ). These differences may be the result of the evolution of different life histories and life styles and spreading into different environments.

Longevity differences between marine, freshwater and terrestrial environments

Longevity is on average lowest in the sea and brackish water ( 6.0 years, $n=132)$, intermediate in fresh water $(7.2$ years, $\mathrm{n}=88$ ) and highest in semiterrestrial and terrestrial environments (13.0 years, n=24) (Fig. 2). The difference between marine and freshwater environments is partly due to the fact that the shorter-lived Dendrobranchiata have not invaded freshwater habitats. Longevity promoting environments are obviously the deep sea, polar waters, freshwater caves and the land. For example, the deep sea shrimps Aristeus antennatus and Aristaeomorpha foliacea have the highest life spans of all investigated Dendrobranchiata and the polar caridean shrimps Notocrangon antarcticus and Sclerocrangon boreas live much longer than crangonids from warmer waters (Table 1). The cave-dwelling shrimp Palaemonias ganteri and crayfish Orconectes australis live much longer than their epigean relatives, and the terrestrial anomurans have considerably higher life spans than their marine and freshwater relatives (Table 1).

\section{Particularly long-lived species}

Species that live for several decades are found in distantly related families like the achelatan Palinuridae (spiny lobsters), astacidean Nephropidae (clawed lobsters) and Parastacidae (southern hemisphere crayfish), anomuran Coenobitidae (hermit and coconut crabs), and brachyuran Menippidae and Inachidae. Examples of the first four families are found in Table 1. Examples of the latter two families are the Tasmanian giant crab Pseudocarcinus gigas (Lamarck, 1818) and the giant Japanese spider crab Macrocheira kaempferi (Temminck, 1836). The ability of these species to live for many decades and even more than 100 years was deduced from their exceptionally large size (e.g., Homarus americanus and Macrocheira kaempferi), slow 
growth and late onset of maturity (e.g., Pseudocarcinus gigas and Astacopsis gouldi), and phases of zero and negative growth at high age (e.g., Birgus latro) (Wolf, 1978; Hamr, 1997; Gardner et al., 2002; Drew et al., 2013). For example, the intermoult duration in adult Pseudocarcinus gigas is about 9 years (Gardner et al., 2002) and the average age at maturity in the giant Tasmanian freshwater crayfish Astacopsis gouldi is approximately 9 years in males and 14 years in females (Hamr, 1997).

\section{Discussion}

The present list of life spans in decapod crustaceans was compiled to provide a first data base for interested carcinologists. Sincelongevity is an important parameter in ecology, fisheries and conservation (Hartnoll, 2001; Cailliet and Andrews, 2008) it may help researchers in these fields with information and literature. I am aware that the compiled data are quite heterogeneous since they were obtained with different ageing methods but having data of diverse quality is better than having no data. The list includes only data obtained with established methods of age determination such as rearing in captivity, mark-recapture method, growth models and the lipofuscin method (Hartnoll, 2001; Vogt, 2012). Data obtained by growth band counts of hard structures that are thought to perist during moulting were not considered because this issue is still controversially discussed (Kilada and Driscoll, 2017; Becker et al., 2018). Future research must show, whether this approach will be a breakthrough in ageing of decapods or a wrong path.

The Decapoda include almost 15,000 species that differ greatly in body size, life history and ecology (De Grave et al., 2009). Almost $80 \%$ live in the sea or brackish water, about $20 \%$ in freshwater and less than $1 \%$ on land. The highest percentage of longevity data is available for the terrestrial species followed by freshwater species. Analysis of the longevity data of 244 species revealed an exceptionally broad range of life spans in the Decapoda when compared to other animal groups and differences between higher taxa and environments.

Longevity in the Decapoda ranges from 0.1 to about 70 years, corresponding to a 700 fold difference. The shortest-lived decapods are planktonic shrimps and the longest-lived decapods are clawed lobsters. In insects, the closest relatives of crustaceans, life span varies from a month in fruit fly to about two decades in queens of termites (Thorne et al., 2002). In bivalves, the longevity range is 1-374 years (Abele et al., 2009), in fishes 1-152 years, in amphibians 1.8-55 years, in reptiles 1-153 years, in birds $1.5-73$ years, and in mammals 1-122 years (Carey and Judge, 2000).

Longevity in decapods apparently depends on taxonomic affiliation. The plesiomorphic Dendrobranchiata have the smallest average live span. They usually live less than 2 years with the exception of some deep-sea representatives. The infraorder with the highest percentage of long-lived species is probably the Achelata, which include slipper lobsters and rock lobsters. However, the coefficient of variation for life spans is high in all infraorders, mostly exceeding $100 \%$. This data indicates that longevity was subject to intense evolution in all infraorders of the Decapoda.

The present compilation of data also shows that longevity is dependent on the environment. Terrestrial species live on average longer than freshwater species, and freshwater species live longer than marine species. In an earlier paper, I have presented examples on the positive correlation of life span and latitude and examples on longevity differences between diverse habitats of the same geographical region (Vogt, 2012). The deep sea, cold polar waters and nutrient-poor cave environments seem to prolong life spans.

It was not my aim to correlate longevity with body size but there is a general tendency that bigger species have long life spans. For example, freshwater crayfish, lobsters, slipper lobsters and some large brachyuran crabs have life spans of decades, whereas small species from these groups life only for 1-2 years. However, there are also some contradictory examples like the shrimps of the genus Penaeus that reach sizes of more than $30 \mathrm{~cm}$ but live only for about 2 years.

The present database gives no information about which method of age determination is the most appropriate one, because studies that have analysed the same population with more than one ageing technique are scarce. For example, in the shrimp Xiphocaris elongata from a Puerto Rican headwater stream longevity was estimated to 11 years by a growth model but recapture of an earlier marked specimen revealed an age of 18 years (Cross et al., 2008).

There is a certain probability that, due to indeterminate growth, some exceptionally large specimens of the long-lived species may become centenarians. However, 


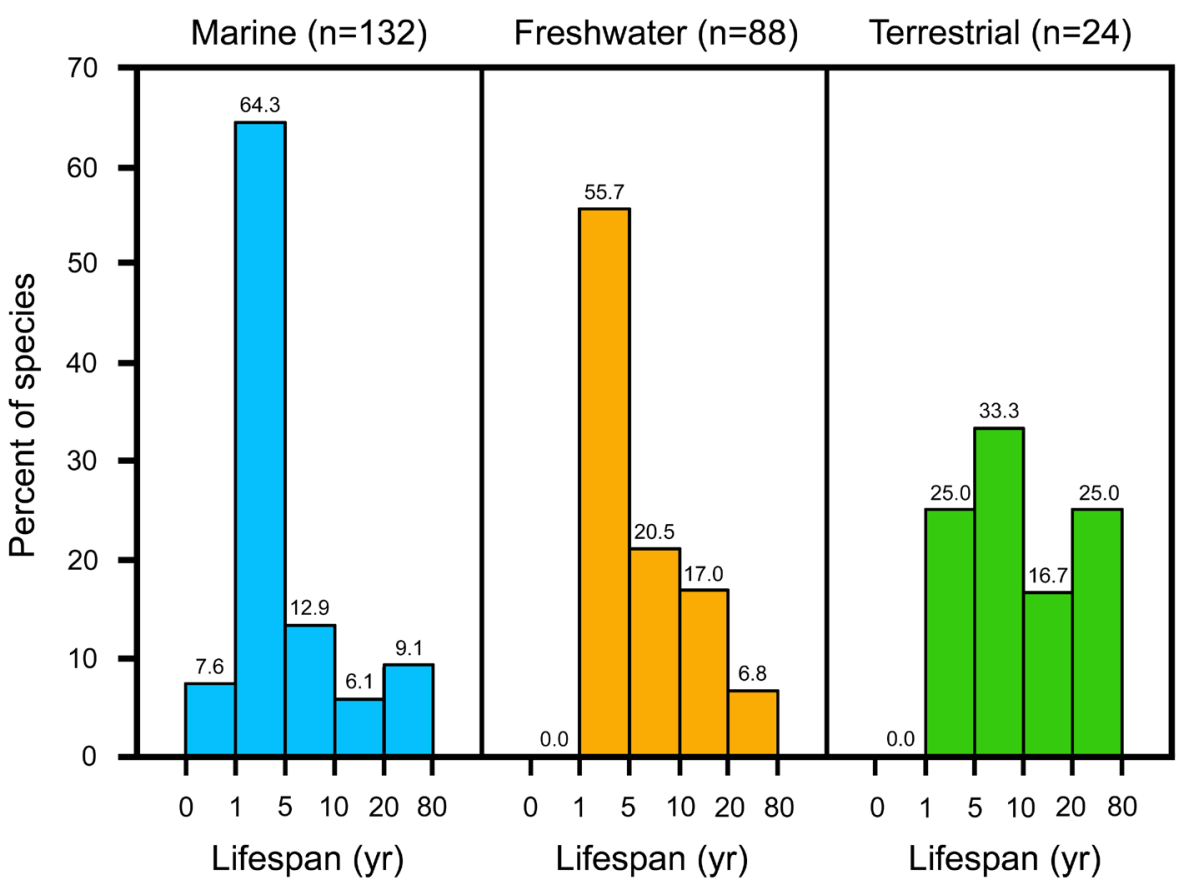

Figure 2. Comparison of longevities between marine, freshwater and terrestrial environments. The percentage of life spans $\geq 5$ years increases markedly from marine to freshwater to terrestrial species. Brackish water species are included in the marine group.

validation would require long-term rearing in captivity over several generations of researchers or recapture of marked specimens in the distant future. Both approaches are principally possible but I doubt if there are scientists who engage in such long-term tasks.

\section{RefERENCES}

Abele, D.; Brey, T. and Philipp, E. 2009. Bivalve models of aging and the determination of molluscan lifespans. Experimental Gerontology, 44: 307-315.

Ahamed, F. and Ohtomi, J. 2012. Growth patterns and longevity of the pandalid shrimp Plesionika izumiae (Decapoda: Caridea). Journal of Crustacean Biology, 32: 733-740.

Ali, M.H.; Salman, S.D. and Al-Adhub, A.J. 1995. Population dynamics of the hymenosomatid crab Elamenopsis kempi in a brackish subtidal region of Basrah, Iraq. Scientia Marina, 59: $1-13$.

Alon, N.C. and Stancyk, S.E. 1982. Variation in life-history patterns of the grass shrimp Palaemonetes pugio in two South Carolina estuarine systems. Marine Biology, 68: 265-276.

Amin, S.M.N.; Arshad, A.; Siraj, S.S.; Sidik, B.J. and Rahman, M.A. 2012. Population biology and stock status of planktonic shrimp Acetes indicus (Decapoda: Sergestidae) in the coastal waters of Malacca, Peninsular, Malaysia. Aquatic Ecosystem Health \& Management, 15: 294-302.

Anantha, C.S.; Bhaskar, N.; Shanbhogue, S.L.; Raghunath, B.S. and Raju, C.V. 1997. Age and growth of the shrimp Parapenaeopsis stylifera (Decapoda/Crustacea) from Mangalore, west coast of India. Indian Journal of Marine Sciences, 26: 221-223.
Animal Diversity Web. 2019a. Coenobita perlatus. Available at https://animaldiversity.org/accounts/Coenobita_perlatus/. Accessed on 5 March 2019.

Animal Diversity Web. 2019b. Ocypode quadrata: Atlantic ghost crab. Available at https://animaldiversity.org/accounts/ Ocypode_quadrata/. Accessed on 23 March 2019.

Ansell, A.D.; Sivadas, P.; Narayanan, B. and Trevallion, A. 1972. The ecology of two sandy beaches in south west India. II. Notes on Emerita holthuisi. Marine Biology, 17: 311-317.

Ariyama, H. 1992. Molting and growth of the swimming crab Portunus (Portunus) trituberculatus reared in the laboratory. Nippon Suisan Gakkaishi, 58: 1799-1805.

Atlas Obscura. 2019. The 40-year-old hermit crab. Available at https://www.atlasobscura.com/articles/the-40yearoldhermit-crab. Accessed on 5 March 2019.

Baker, A.M.; Stewart, P.M. and Simon, T.P. 2008. Life history study of Procambarus suttkusi in Southeastern Alabama. Journal of Crustacean Biology, 28: 451-460.

Baldwin, A.P. and Bauer, R.T. 2003. Growth, survivorship, lifespan, and sex change in the hermaphroditic shrimp Lysmata wurdemanni (Decapoda: Caridea: Hippolytidae). Marine Biology, 143: 157-166.

Barcelos, D.F.; Castiglioni, D.S.; Barutot, R.A. and Santos, S. 2007. Crescimento de Chasmagnathus granulatus (Crustacea, Decapoda, Varunidae) na Lagoa do Peixe, Rio Grande do Sul, Brasil. Inheringia, Serie Zoologia, 97: 263-267.

Bauer, R.T. 2004. Remarkable shrimps: adaptations and natural history of the carideans. Norman, University of Oklahoma Press, 316p.

Beck, J.T. and Cowell, B.C. 1976. Life history and ecology of the freshwater caridean shrimp, Palaemonetes paludosus (Gibbes). American Midland Naturalist, 96: 52-65. 
Becker, C.; Dick, J.T.A.; Cunningham, E.M.; Schmitt, C. and Sigwart, J.D. 2018. The crustacean cuticle does not record chronological age: new evidence from the gastric mill ossicles. Arthropod Structure \& Development, 47: 498-512.

Belchier, M.; Edsman, L.; Sheehy, M.R.J. and Shelton, P.M.J. 1998. Estimating age and growth in long-lived temperate freshwater crayfish using lipofuscin. Freshwater Biology, 39: 439-446.

Bell, J.L. and Stancyk, S.E. 1983. Population dynamics and reproduction of Dissodactylus mellitae (Brachyura: Pinnotheridae) on its sand dollar host Mellita quinquiesperforata (Echinodermata). Marine Ecology Progress Series, 13: 141-149.

Bell, M.C.; Redant, F. and Tuck, I. 2006. Nephrops species. p. 412-461. In: B. Phillips (ed), Lobsters: biology, management, aquaculture and fisheries. Oxford, Blackwell.

Berner, L. 1952. Biologie de Pinnotheres pisum Penn. (Dećapode, Brachyoure). Bulletin de la Société zoologique de France, 77: 344-349.

BIOTIC. 2019. Species Information for Cancer pagurus. Biological Traits Information Catalogue, MarLIN - The Marine Life Information Network for Britain \& Ireland. Available at http://www.marlin.ac.uk/biotic/browse.php?sp=4129. Accessed on 7 March 2019.

Bluhm, B.A. and Brey, T. 2001. Age determination in the Antarctic shrimp Notocrangon antarcticus (Crustacea: Decapoda), using the autofluorescent pigment lipofuscin. Marine Biology, 138: 247-257.

Boos Jr., H.; Silva-Castiglioni, D.; Schacht, K.; Buckup, L. and Bond-Buckup, G. 2006. Crescimento de Aegla jarai BondBuckup \& Buckup (Crustacea, Anomura, Aeglidae). Revista brasileira de Zoologia, 23: 490-496.

Brown, J.H.; New, M.B. and Ismael, D. 2010. Biology. p. 18-39. In: M.B. New; W.C. Valenti; J.H. Tidwell; L.R. D’Abramo and M.N. Kutty (eds), Freshwater prawns: biology and farming. Oxford, Blackwell.

Buřič, M.; Kozák, P. and Vích, P. 2008. Evaluation of different marking methods for spiny cheek crayfish (Orconectes limosus). Knowledge and Management of Aquatic Ecosystems, 389: 02.

Cailliet, G.M. and Andrews, A.H. 2008. Age-validated longevity of fishes: its importance for sustainable fisheries. p. 103-120. In: K. Tsukamoto; T. Kawamura; T. Takeuchi; T.D. Beard Jr. and M.J. Kaiser (eds), Fisheries for global welfare and environment, Memorial book of the 5th World Fisheries Congress 2008. Tokyo, TerraPub.

Canales, C. and Arana, P.M. 2009. Crecimiento, mortalidad y evaluación de la población de cangrejo dorado (Chaceon chilensis) explotado en el archipiélago de Juan Fernández, Chile. Latin American Journal of Aquatic Research, 37: 313-326.

Carey, J.R. and Judge, D.S. 2000. Longevity records: life spans of mammals, birds, amphibians, reptiles, and fish. Monographs on Population Aging 8. Odense, University Press of Southern Denmark, 241p.

Castilho, A.L.; Bauer, R.T.; Freire, F.A.M.; Fransozo, V.; Costa, R.C.; Grabowski, R.C. and Fransozo, A. 2015. Lifespan and reproductive dynamics of the commercially important sea bob shrimp Xiphopenaeus kroyeri (Penaeoidea): synthesis of a 5-year study. Journal of Crustacean Biology, 35: 30-40.

Cha, H.K.; Oh, C.W. and Choi, J.H. 2004. Biology of the cocktail shrimp, Trachysalambria curvirostris (Decapoda: Penaeidae) in the Yellow Sea of Korea. Journal of the Marine Biological Association of the United Kingdom, 84: 351-357.

Chávez, E.A. 1973. A study on the growth rate of brown shrimp (Penaeus aztecus aztecus Ives, 1891) from the coasts of Veracruz and Tamaulipas, Mexico. Gulf Research Reports, 4: 278-299.

Choi, J.H.; Kim, J.N.; Ma, C.W. and Cha, H.K. 2005. Growth and reproduction of the kishi velvet shrimp Metapenaeopsis dalei (Rathbun, 1902) (Decapoda, Penaeidae) in the western sea of Korea. Crustaceana, 78: 947-963.

Christensen, A.M. and McDermott, J.J. 1958. Life-history and biology of the oyster crab, Pinnotheres ostreum Say. Biological Bulletin, 114: 146-179.

Chucholl, C. 2011. Population ecology of an alien "warm water" crayfish (Procambarus clarkii) in a new cold habitat. Knowledge and Management of Aquatic Ecosystems, 401: 29.

Chute, A.; Jacobson, L.; Rago, P. and MacCall, A. 2008. Deep sea red crab. p. 181-198. In: Northeast Data Poor Stocks Working Group Meeting, Woods Hole, MA, Dec. 8-12, 2008.

Clark, R.L. 1987. Aspects of growth and reproduction of the hairy handed crab, Hemigrapsus crenulatus (Brachyura: Grapsidae). Christchurch, University of Canterbury, M. Sc. Thesis. 159p. [Unpublished].

Cohen, F.P.A.; Takano, P.F.; Shimizu, R.M. and Bueno, S.L.S. 2011. Life cycle and population structure of Aegla paulensis (Decapoda: Anomura: Aeglidae). Journal of Crustacean Biology, 31: 389-395.

Colloca, F. 2002. Life cycle of the deep-water pandalid shrimp Plesionika edwardsii (Decapoda, Caridea) in the central Mediterranean Sea. Journal of Crustacean Biology, 22: 775-783.

Conde, J.E.; Tognella, M.M.P.; Paes, E.T.; Soares, M.L.G.; Louro, I.A. and Schaeffer Novelli, Y. 2000. Population and life history features of the crab Aratus pisonii (Decapoda: Grapsidae) in a subtropical estuary. Interciencia, 25: 151-158.

Conides, A.J.; Nicolaidou, A.; A postolopoulou, M. and ThessalouLegaki, M. 2012. Growth, mortality and yield of the mudprawn Upogebia pusilla (Petagna, 1792) (Crustacea: Decapoda: Gebiidea) from western Greece. Acta Adriatica, 53: 87-103.

Cooper, J. 1975. Ecological and behavioral studies in Shelta Cave, Alabama, with emphasis on decapod crustaceans. University of Kentucky, Lexington, Kentucky, PhD Thesis. 364p. [Unpublished].

Costa, T.M.; Pitombo, F.P. and Soares-Gomes, A. 2014. The population biology of the exploited crab Ucides cordatus (Linnaeus, 1763) in a south eastern Atlantic coast mangrove area, Brazil. Invertebrate Reproduction and Development, 58: 259-268.

Crane, J. 1975. Fiddler crabs of the world: Ocypodidae, genus Uca. Princeton, Princeton University Press, 400p.

Cross, W.F.; Covich, A.P.; Crowl, T.A.; Benstead, J.P. and Ramírez, A. 2008. Secondary production, longevity and resource consumption rates of freshwater shrimps in two tropical streams with contrasting geomorphology and food web structure. Freshwater Biology, 53: 2504-2519.

Cumberlidge, N. 1999. The freshwater crabs of West Africa: family Potamonautidae. Paris, IRD Éditions, 385p.

Davis, J.L.D.; Young-Williams, A.C.; Hines, A.H. and Zmora, O. 2004. Comparing two types of internal tags in juvenile blue crabs. Fisheries Research, 67: 265-274. 
De Grave, S.; Pentcheff, N.D.; Ahyong, S.T.; Chan, T.Y.; Crandall, K.A.; Dworschak, P.C.; Felder, D.L.; Feldmann, R.M.; Fransen, C.H.J.M.; Goulding, L.Y.D.; Lemaitre, R.; Low, M.E.Y.; Martin, J.W.; Ng, P.K.L.; Schweitzer, C.E.; Tan, S.H.; Tshudy, D. and Wetzer, R. 2009. A classification of living and fossil genera of decapod crustaceans. Raffles Bulletin of Zoology, Supplement 21: 1-109.

De Lestang, S.; Hall, N.G. and Potter, I.C. 2003. Reproductive biology of the blue swimmer crab (Portunus pelagicus, Decapoda: Portunidae) in five bodies of water on the west coast of Australia. Fisheries Bulletin (Washington), 101: 745-757.

De Silva, K.H.G.M. 1988a. Studies on Atyidae (Decapoda, Caridea) of Sri Lanka. IV. Some aspects of the population ecology of the endemic freshwater shrimp Caridina pristis Roux, 1931. Crustaceana, 54: 225-243.

De Silva, K.H.G.M. 1988b. Studies on Atyidae (Decapoda, Caridea) of Sri Lanka. III. Aspects of the population ecology of Caridina simoni Bouvier, 1904. Crustaceana, 54: 85-103.

Deval, M.C.; Bök, T.; Ateş, C. and Tosunoğlu, Z. 2007. Lengthbased estimates of growth parameters, mortality rates, and recruitment of Astacus leptodactylus (Eschscholtz, 1823) (Decapoda, Astacidae) in unexploited inland waters of the northern Marmara region, European Turkey. Crustaceana, 80: 655-665.

Dhaouadi-Hassen, S. and Boumaïza, M. 2009. Reproduction and population dynamics of Atyaephyra desmarestii (Decapoda, Caridea) from the Sidi Salem dam Lake (northern Tunisia). Crustaceana, 82: 129-139.

Diaz, H. 1980. The mole crab Emerita talpoida (Say). A case of life history patterns. Ecological Monographs, 50: 437-456.

Diesel, R. and Horst, D. 1995. Breeding in a snail shell: ecology and biology of the Jamaican montane crab Sesarma jarvisi (Decapoda: Grapsidae). Journal of Crustacean Biology, 15: 179-195.

Diez, M.J. and Lovrich, G.A. 2013. Moult cycle and growth of the crab Halicarcinus planatus (Brachyura, Hymenosomatidae) in the Beagle Channel, southern tip of South America. Helgoland Marine Research, 67: 555-566.

Dineshbabu, A.P. and Manissery, J.K. 2007. Morphometric relationship and growth of the 'ridge back shrimp' Solenocera choprai (Decapoda/Crustacea) from Mangalore (southwest coast of India). Indian Journal of Marine Sciences, 36: 65-70.

Doi, W.; Yokota, M.; Strüssmann, C.A. and Watanabe, S. 2008. Growth and reproduction of the portunid crab Charybdis bimaculata (Decapoda: Brachyura) in Tokyo Bay. Journal of Crustacean Biology, 28: 641-651.

Donaldson, W.E.; Cooney, R.T. and Hilsinger, J.R. 1981. Growth, age and size at maturity of tanner crab, Chionoecetes bairdi M. J. Rathbun, in the northern Gulf of Alaska (Decapoda, Brachyura). Crustaceana, 40: 286-302.

Drew, M.M.; Smith, M.J. and Hansson, B.S. 2013. Factors influencing growth of giant terrestrial robber crab Birgus latro (Anomura: Coenobitidae) on Christmas Island. Aquatic Biology, 19: 129-141.

Ehrhardt, N.M. 2008. Estimating growth of the Florida spiny lobster, Panulirus argus, from molt frequency and size increment data derived from tag and recapture experiments. Fisheries Research, 93: 332-337.
Ernst, B.; Orensanz, J.M. and Armstrong, D.A. 2005. Spatial dynamics of female snow crab (Chionoecetes opilio) in the eastern Bering Sea. Canadian Journal of Fisheries and Aquatic Sciences, 62: 250-268.

FAO. 2019. Lobsters. Available at http://www.fao.org/3/r7066e/ r7066e27.pdf. Accessed on 15 March 2019.

Farhana, F. and Ohtomi, J. 2017. Growth pattern and longevity of Parapenaeus fissuroides Crosnier, 1985 (Decapoda, Penaeidae) in Kagoshima Bay, southern Japan. Crustaceana, 90: 153-166.

Fletcher, W.J.; Brown, I.W. and Fielder, D.R. 1990. Growth of the coconut crab Birgus latro in Vanuatu. Journal of Experimental Marine Biology and Ecology, 141: 63-78.

Fidalgo, M.L.; Santos, P.; Ferreira, C. and Silva, A. 2015. Population structure and dynamics of the freshwater shrimp Atyaephyra desmarestii (Millet, 1831) in the lower river Minho (NW Portugal). Crustaceana, 88: 657-673.

Flint, R.W. 1975. The natural history, ecology and production of the crayfish, Pacifastacus leniusculus, in a subalpine lacustrine environment. Davis, University of California, Ph.D. Dissertation, 150p. [Unpublished].

Fonseca, D.B. and Sheehy, M.R.J. 2007. Does size matter? A cautionary experiment on overoptimism in length-based bioresource assessment. Canadian Journal of Fisheries and Aquatic Sciences, 64: 996-1008.

Fonseca, D.B.; Sainte-Marie, B. and Hazel, F. 2008. Longevity and change in shell condition of adult male snow crab Chionoecetes opilio inferred from dactyl wear and mark-recapture data. Transactions of the American Fisheries Society, 137: 1029-1043.

Fontura, N.F. and Buckup, L. 1989. O crescimento de Parastacus brasiliensis (Von Martens, 1869) (Crustacea, Decapoda, Parastacidae). Revista Brasileira de Biologia, 49: 897-909.

Furota, T. 1996. Life cycle studies on the introduced spider crab Pyromaia tuberculata (Lockington) (Brachyura: Majidae). II. Crab stage and reproduction. Journal of Crustacean Biology, 16: 77-91.

Furota, T.; Watanabe, S.; Watanabe, T.; Akiyama, S. and Kinoshita, K. 1999. Life history of the Mediterranean green crab, Carcinus aestuarii Nardo, in Tokyo Bay, Japan. Crustacean Research, 28: 5-15.

Gao, T. and Watanabe, S. 1998. Growth and reproduction of Rhynchoplax messor Stimpson (Brachyura: Hymenosomatidae). Journal of Ocean University of Qingdao, 28: 405-409.

Gao, T.; Tsuchida, S. and Watanabe, S. 1994. Growth and reproduction of Rhynchoplax coralicola Rathun (Brachyura: Hymenosomatidae). Crustacean Research, 23: 108-116.

Garcia. J.R.; Wolf, M.R.; Costa, R.C. and Castilho, A.L. 2016. Growth and reproduction of the shrimp Rimapenaeus constrictus (Decapoda: Penaeidae) from the southeastern coast of Brazil. Regional Studies in Marine Science, 6: 1-9.

Gardner, C.; Jenkinson, A. and Heijnis, H. 2002. Estimating intermolt duration in giant crabs (Pseudocarcinus gigas). $\mathrm{p}$. 17-28. In: A.J. Paul; E.G. Dawe; R. Elner; G.S. Jamieson; G.H. Kruse; R.S. Otto; B. Sainte-Marie; T.C. Shirley and D. Woodby (eds), Crabs in cold water regions: biology, management, and economics. Fairbanks, Alaska Sea Grant.

Gavio, M.A.; Orensanz, J.M. and Armstrong, D. 2006. Evaluation of alternative life history hypotheses for the sand shrimp 
Crangon franciscorum (Decapoda: Caridea). Journal of Crustacean Biology, 26: 295-307.

Gherardi, F.; Souty-Grosset, C.; Vogt, G.; Diéguez-Uribeondo, J. and Crandall, K.A. 2010. Infraorder Astacidea Latreille, 1802. The freshwater crayfish. p. 269-423. In: F.R. Schram and J.C. von Vaupel Klein (eds), Treatise on zoology - anatomy, taxonomy, biology. The Crustacea, vol. 9, part A: Eucarida: Euphausiacea, Amphionidacea, and Decapoda (partim). Brill, Leiden.

Ghia, D.; Fea, G.; Conti, A.; Sacchi, R. and Nardi, P.A. 2015. Estimating age composition in Alpine native populations of Austropotamobius pallipes complex. Journal of Limnology, 74: 501-511.

Gilligan, D.; Rolls, R.; Merrick, J.; Lintermans, M.; Duncan, P. and Kohen, J. 2007. Scoping the knowledge requirements for Murray crayfish (Euastacus armatus). Fisheries Final Report Series 89. Narrandera, Australia, NSW Department of Primary Industries, Aquatic Ecosystems Research, Narrandera Fisheries Centre. 103p.

Gnanalingam, G.; Butler IV, M.J.; Matthews, T.R.; Hutchinson, E. and Kilada, R. 2019. Directly ageing the Caribbean spiny lobster, Panulirus argus, with validated band counts from gastric mill ossicles. ICES Journal of Marine Science, 76: 442-451.

Gorny, M.; Brey, T.; Arntz, W. and Bruns, T. 1993. Growth, development and productivity of Chorismus antarcticus (Pfeffer) (Crustacea: Decapoda: Natantia) in the eastern Weddell Sea, Antarctica. Journal of Experimental Marine Biology and Ecology, 174: 261-275.

Green, P.T. 2004. Field observations of moulting and moult increment in the red land crab, Gecarcoidea natalis (Brachyura, Gecarcinidae), on Christmas Island (Indian Ocean). Crustaceana, 77: 125-128.

Guéguen, F. 1998. Biologie de la crevette profonde Solenocera acuminata en Guyane française. Comptes rendus de l'Académie des sciences, Sciences de la vie, 321: 385-394.

Guerao, G.; Pérez-Baquera, J. and Ribera, C. 1994. Growth and reproductive biology of Palaemon xiphias Risso, 1816 (Decapoda: Caridea: Palaemonidae). Journal of Crustacean Biology, 14: 280-288.

Guiaşu, R.C. and Dunham, D.W.2002. Observations on the timing of moulting events in the crayfish Cambarus robustus Girard, 1852 (Decapoda, Cambaridae). Crustaceana, 74: 1365-1378.

Hamr, P. 1997. A giant's tale: The life history of Astacopsis gouldi (Decapoda: Parastacidae), a freshwater crayfish from Tasmania. Freshwater Crayfish, 11: 13-33.

Hamr, P. and Richardson, A. 1994. Life history of Parastacoides tasmanicus tasmanicus Clark, a burrowing fresh-water crayfish from south-western Tasmania. Australian Journal of Marine and Freshwater Research, 45: 455-470.

Hartnoll, R.G. 2001. Growth in Crustacea - twenty years on. Hydrobiology, 449: 111-122.

Hartnoll, R.G. 2009. Sexual maturity and reproductive strategy of the rock crab Grapsus adscensionis (Osbeck, 1765) (Brachyura, Grapsidae) on Ascension Island. Crustaceana, 82: 275-291.

Hartnoll, R.G. and Bryant, A.D. 2001. Growth to maturity of juveniles of the spider crabs Hyas coarctatus Leach and Inachus dorsettensis (Pennant) (Brachyura: Majidae). Journal of Experimental Marine Biology and Ecology, 263: 143-158.

Hartnoll, R.G.; Baine, M.S.P.; Grandas, Y.; James, J. and Atkin, H. 2006. Population biology of the black land crab, Gecarcinus ruricola, in the San Andres Archipelago, western Caribbean. Journal of Crustacean Biology, 26: 316-325.

Henmi, Y. 1993. Geographic variations in life-history traits of the intertidal ocypodid crab Macrophthalmus banzai. Oecologia, 96: 324-330.

Herborg, L.M.; Rushton, S.P.; Clare, A.S. and Bentley, M.G. 2003. Spread of the Chinese mitten crab (Eriocheir sinensis H. Milne Edwards) in Continental Europe: analysis of a historical data set. Hydrobiologia, 503: 21-28.

Hiatt, R.W. 1948. The biology of the lined shore crab, Pachygrapsus crassipes Randall. Pacific Science, 2: 134-213.

Hines, A.H. 1991. Fecundity and reproductive output in nine species of Cancer crabs (Crustacea, Brachyura, Cancridae). Canadian Journal of Fisheries and Aquatic Sciences, 48: 267-275.

Holdich, D.M. 1993. A review of astaciculture: freshwater crayfish farming. Aquatic Living Resources, 6: 307-317.

Hossain, J. and Ohtomi, J. 2010. Growth of the southern rough shrimp Trachysalambria curvirostris (Penaeidae) in Kagoshima Bay, Southern Japan. Journal of Crustacean Biology, 30: 75-82.

Huner, J.V. 2002. Procambarus. p. 541-584. In: D.M. Holdich (ed), Biology of freshwater crayfish. Oxford, Blackwell.

Huryn, A.D. and Wallace, J.B. 1987. Production and litter processing by crayfish in an Appalachian mountain stream. Freshwater Biology, 18: 277-286.

Jennings, S.; Kaiser, M.J. and Reynolds, J.D. 2001. Marine fisheries ecology. Oxford, Blackwell, 432p.

Jin, G.; Xie, P. and Li, Z. 2002. The precocious Chinese mitten crab: changes of gonad, survival rate, and life span in a freshwater lake. Journal of Crustacean Biology, 22: 411-415.

Johnston, C.E. and Figiel, C. 1997. Microhabitat parameters and life-history characteristics of Fallicambarus gordoni Fitzpatrick, a crayfish associated with pitcher-plant bogs in southern Mississippi. Journal of Crustacean Biology, 17: 687-691.

Jones, J.P.G. and Coulson, T. 2006. Population regulation and demography in a harvested freshwater crayfish from Madagascar. Oikos, 112: 602-611.

Jones, D.R. and Eversole, A.G. 2011. Life history characteristics of the Elk River Crayfish. Journal of Crustacean Biology, 31: 647-652.

Jones, J.P.G.; Andriahajaina, F.B.; Hockley, N.J.; Crandall, K.A. and Ravoahangimalala, O.R. 2007. The ecology and conservation status of Madagascar's endemic freshwater crayfish (Parastacidae; Astacoides). Freshwater Biology, 52: 1820-1833.

Jung, T.; Bader, N. and Grune, T. 2007. Lipofuscin: formation, distribution, and metabolic consequences. Annals of the New York Academy of Sciences, 1119: 97-111.

Kawai, T.; Hamano, T. and Matsuura, S. 1997. Survival and growth of the Japanese crayfish Cambaroides japonicus in a small stream in Hokkaido. Bulletin of Marine Science, 61: 147-157.

Kawane, M.; Wada, K.; Umemoto, A. and Miura, T. 2012. Genetic population structure and life history characteristics of the rare brackish-water crab Deiratonotus kaoriae Miura, Kawane and Wada, 2007 (Brachyura: Camptandriidae) in western Japan. Journal of Crustacean Biology, 32: 119-125.

Kevrekidis, T.; Gouvis, N. and Koukouras, A. 1997. Population dynamics, reproduction and growth of Upogebia pusilla (Decapoda, Thalassinidea) in the Evros delta (north Aegean Sea). Crustaceana, 70: 799-812. 
Kilada, R. and Driscoll, J.G. 2017. Age determination in crustaceans: a review. Hydrobiologia, 799: 21-36.

Kilada, R.; Sainte-Marie, B.; Rochette, R.R.; Davis, N.; Vanier, C. and Campana, S. 2012. Direct determination of age in shrimps, crabs, and lobsters. Canadian Journal of Fisheries and Aquaculture Science, 69: 1728-1733.

Kim, J.C.; Ma, C.W.; Oh, C.W. and Paik, S.G. 2008. Reproduction and growth of the freshwater prawn, Palaemon paucidens (Decapoda: Palaemonidae) in a lake of Korea. Journal of Environmental Biology, 29: 163-168.

Klassen, G. and Locke, A. 2007. Biological synopsis of the European Green Crab, Carcinus maenas. Canadian Manuscript Report of Fisheries and Aquatic Sciences No. 2818, 75p.

Kobayashi, S. 2012. Molting growth patterns of the Japanese mitten crab Eriocheir japonica (De Haan) under laboratoryreared conditions. Journal of Crustacean Biology, 32: 753-761.

Koch, V.; Wolff, M. and Diele, K. 2005. Comparative population dynamics of four fiddler crabs (Ocypodidae, genus Uca) from a North Brazilian mangrove ecosystem. Marine Ecology Progress Series, 291: 177-188.

Koeller, P.A. 2006. Inferring shrimp (Pandalus borealis) growth characteristics from life history stage structure analysis. Journal of Shellfish Research, 25: 595-608.

Kornienko, E.S. 2013. Burrowing shrimp of the infraorders Gebiidea and Axiidea (Crustacea: Decapoda). Russian Journal of Marine Biology, 39: 1-14.

Kunju, M.M. 1969. Prawn fisheries of India. VI: Genera Solenocera Lucas 1850, Atypopenaeus Alcock 1905, Hyppolysmata Stimpson 1860, Palaemon Weber 1795 and Acetes M. Edwards 1830. Bulletin of the Central Marine Fisheries Research Institute, 14: 159-177.

Lee, W.J.; Omori, M. and Peck, R.W. 1992. Growth, reproduction and feeding behavior of the planktonic shrimp, Lucifer faxoni Borradaile, off the Texas coast. Journal of Plankton Research, 14: 61-69.

Le Foll, D. 1993. Biologie et exploitation de l'araignée de mer Maja squinado (Herbst) en Manche ouest. Brest, Université de Bretagne Occidentale, Ph.D. Thesis, 517p. [Unpublished].

Leite Jr., N.O. and Petrere Jr., M. 2006. Growth and mortalities of the pink-shrimp Farfantepenaeus brasiliensis Latreille, 1970 and F. paulensis Pérez-Farfante 1967 in southeast Brazil. Brazilian Journal of Biology, 66: 523-536.

Leland, J.C.; Coughran, J. and Bucher, D.J. 2011. A preliminary investigation into the potential value of gastric mills for ageing crustaceans. p. 57-68. In: A. Asakura (ed), New frontiers in crustacean biology. Leiden, Brill.

Leme, M.H.A. 2002. A comparative analysis of the population biology of the mangrove crabs Aratus pisonii and Sesarma rectum (Brachyura, Grapsidae) from the north coast of São Paulo State, Brazil. Journal of Crustacean Biology, 22: 553-557.

Leung, S.F. 1997. The population dynamics of Metapenaeus ensis (Crustacea: Decapoda: Penaeidae) in a traditional tidal shrimp pond at the Mai Po Marshes Nature Reserve, Hong Kong. Journal of Zoology, 242: 77-96.

Lindner, M.J. and Cook, H.L. 1970. Synopsis of biological data on the white shrimp Penaeus setiferus (Linnaeus, 1767). FAO Fisheries Synopsis, 101: 1440-1469.

Lopes, D.F.C.; Silva, E.F.B.; Peixoto, S.R.M. and Frédou, F.L. 2014. Population biology of seabob-shrimp Xiphopenaeus kroyeri
(Heller, 1862) captured on the south coast of Pernambuco state, northeastern Brazil. Brazilian Journal of Oceanography, 62: 331-340.

Lopes, A.E.B.; Grabowski, R.C.; Garcia, J.R.; Fransozo, A.; Costa, R.C.; Hiroki, K.A.N. and Castilho, A.L. 2017. Population dynamics of Rimapenaeus constrictus (Stimpson, 1874) (Penaeoidea) on the southeastern Brazilian coast: implications for shrimp fishing management from a 5-year study on a bycatch species. Anais da Academia Brasileira de Ciências, 89: 1013-1025.

López-Martínez, J.; Rábago-Quiroz, C.; Nevárez-Martínez, M.O.; García-Juárez, A.R.; Rivera-Parra, G. and Chávez-Villalba, J. 2005. Growth, reproduction, and size at first maturity of blue shrimp, Litopenaeus stylirostris (Stimpson, 1874) along the east coast of the Gulf of California, Mexico. Fisheries Research, 71: 93-102.

Loughman, Z.J. 2010. Ecology of Cambarus dubius (upland burrowing crayfish) in north-central West Virginia. Southeastern Naturalist, 9: 217-230.

Lucas, J.S. 1980. Spider crabs of the family Hymenosomatidae (Crustacea; Brachyura) with particular reference to Australian species: systematics and biology. Records of the Australian Museum, 33: 148-247.

Lukhaup, C. and Pekny, R. 2008. Süßwasserkrebse aus aller Welt, 2. Auflage. Ettlingen, Germany, Dähne Verlag, 256p.

Luppi, T.A.; Spivak, E.D.; Bas, C.C. and Anger, K. 2004. Molt and growth of an estuarine crab, Chasmagnathus granulatus (Brachyura: Varunidae), in Mar Chiquita coastal lagoon, Argentina. Journal of Applied Ichthyology, 20: 333-344.

Mantel, S.K.and Dudgeon, D. 2005. Reproduction and sexual dimorphism of the palaemonid shrimp Macrobrachium hainanense in Hong Kong streams. Journal of Crustacean Biology, 25: 450-459.

Mantelatto, F.L.; Christofoletti, R.A. and Valenti, W.C. 2005. Population structure and growth of the hermit crab Pagurus brevidactylus (Anomura: Paguridae) from the northern coast of São Paulo, Brazil. Journal of the Marine Biological Association of the United Kingdom, 85: 127-128.

Matsuura, S. and Takeshita, K. 1990. Longevity of red king crab, Paralithodes camtschatica, revealed by long-term rearing study. p. 181-188. In: S. Keller (ed), Proceedings of the International Symposium on King and Tanner Crabs, Anchorage, Alaska, 1989. Fairbanks, University of Alaska Press.

Maxwell, K.E.; Matthews, T.R.; Sheehy, M.R.J.; Bertelsen, R.D. and Derby, C.D. 2007. Neurolipofuscin is a measure of age in Panulirus argus, the Caribbean spiny lobster, in Florida. Biological Bulletin, 213: 55-66.

McLay, C.L. 2015. Moulting and growth in Brachyura. p. 245-316. In: P. Castro; P.J.F. Davie; D. Guinot; F.R. Schram and J.C. von Vaupel Klein (eds), Treatise on zoology - anatomy, taxonomy, biology. The Crustacea, Volume 9C, Part1: Decapoda, Brachyura 1. Leiden, Brill.

McLay, C.L. and van den Brink, A.M. 2016. Crayfish growth and reproduction. p. 62-116. In: M. Longshaw and P. Stebbing (eds), Biology and ecology of crayfish. Boca Raton, CRC Press.

Melville-Smith, R. 1989. A growth model for the deep-sea red crab (Geryon maritae) off south west Africa/Namibia (Decapoda, Brachyura). Crustaceana, 56: 279-292. 
Miazaki, L.F.; Simões, S.M.; Castilho, A.L. and Costa, R.C. 2019. Population dynamics of the crab Hepatus pudibundus (Herbst, 1785) (Decapoda, Aethridae) on the southern coast of São Paulo state, Brazil. Journal of the Marine Biological Association of the United Kingdom, 99: 867-878.

Mossolin, E.C.; Shimizu, R.M. and Bueno, S.L.S. 2006. Population structure of Alpheus armillatus (Decapoda, Alpheidae) in São Sebastião and Ilhabela, southeastern Brazil. Journal of Crustacean Biology, 26: 48-54.

Motoh, H. 1981. Studies on the fisheries biology of the giant tiger prawn, Penaeus monodon in the Philippines. Technical Report No. 7. Tigbauan, Philippines, Aquaculture Department, Southeast Asian Fisheries Development Center, 128p.

NBC2 News. 2018. 42-year old pet hermit crab and owner are hit at Fort Myers retirement community. Available at https: / / www.nbc-2.com/clip/14702689/42-year-old-pet-hermitcrab-and-owner-are-hit-at-fort-myers-retirement-community. Accessed on 25 March 2019.

Neveu, A. 2000. Étude des populations d'Austropotamobius pallipes (Crustacea, Astacidae) dans un ruisseau forestier de Normandie. I. Structures démographiques et croissance: stabilité et variabilité au cour de six années. Bulletin Français de la Pêche et de la Pisciculture, 356: 71-98.

Niamaimandi, N.; Arshad, A.B.; Daud, S.K.; Saed, R.C. and Kiabi, B. 2007. Population dynamic of green tiger prawn, Penaeus semisulcatus (De Haan) in Bushehr coastal waters, Persian Gulf. Fisheries Research, 86: 105-112.

Nilssen, E.M. and Aschan, M.M. 2009. Catch, survey and lifehistory data for shrimp (Pandalus borealis) off Jan Mayen. Deep-Sea Research II, Topical Studies in Oceanography, 56: 2023-2036.

Noro, C.K. and Buckup, L. 2009. O crescimento de Parastacus defossus (Crustacea: Decapoda: Parastacidae). Zoologia, 26: 54-60.

Norrocky, M.J. 1991. Observations on the ecology, reproduction and growth of the burrowing crayfish Fallicambarus (Creaserinus) fodiens (Decapoda: Cambaridae) in Northcentral Ohio. American Midland Naturalist, 125: 75-86.

Oh, C.W. and Jeong, I.J. 2003. Reproduction and population dynamics of Acetes chinensis (Decapoda: Sergestidae) on the western coast of Korea, Yellow Sea. Journal of Crustacean Biology, 23: 827-835.

Oh, C.W.; Hartnoll, R.G. and Nash, R.D.M. 1999. Population dynamics of the common shrimp, Crangon crangon (L.), in Port Erin Bay, Isle of Man, Irish Sea. ICES Journal of Marine Science, 56: 718-733.

Oh, C.W.; Suh, H.L.; Park, K.Y.; Ma, C.W. and Lim, H.S. 2002. Growth and reproductive biology of the freshwater shrimp Exopalaemon modestus (Decapoda: Palaemonidae) in a lake of Korea. Journal of Crustacean Biology, 22: 357-366.

Ohtomi, J. 1997. Reproductive biology and growth of the deepwater pandalid shrimp Plesionika semilaevis (Decapoda: Caridea). Journal of Crustacean Biology, 17: 81-89.

Ohtomi, J. and Irieda, S. 1997. Growth of the deep-water mud shrimp Solenocera melantho de Man, 1907 (Decapoda, Penaeoidea, Solenoceridae) in Kagoshima Bay, southern Japan. Crustaceana, 70: 45-58.

Orsi Relini, L. and Relini, G. 1998. Seventeen instars of adult life in female Aristeus antennatus (Crustacea: Decapoda:
Aristeidae). A new interpretation of life span and growth. Journal of Natural History, 32: 1719-1734.

Osório, C.; Bahamonde, N. and Lopez, M.T. 1967. El limanche [Emerita analoga (Stimpson)] en Chile (Crustacea, Decapoda, Anomura). Boletin del Museo Nacional de Historia Natural, Santiago, Chile, 29: 63-105.

Palacios, J.A.; Rodríguez, J.A. and Angulo, R.A. 1993. Estructura poblacional de Penaeus stylirostris (Decapoda: Penaeidae), en el Golfo de Nicoya, Costa Rica. Revista de Biologica Tropical, 41: 233-237.

Parkyn, S.M.; Collier, K.J. and Hicks, B.J. 2002. Growth and population dynamics of crayfish Paranephrops planifrons in streams within native forest and pastoral land uses. New Zealand Journal of Marine and Freshwater Research, 36: 847-861.

Pauley, G.B.; Armstrong, D.A.; Van Citter, R. and Thomas, G.L. 1989. Species profiles: life histories and environmental requirements of coastal fishes and invertebrates (Pacific Southwest). Dungeness crab. Biology Report 82 (11.121). Slidell, U.S. Fish and Wildlife Service, 20p.

Phillips, B.F. and Melville-Smith, R. 2006. Panulirus species. p. 359-384. In: B. Phillips (ed), Lobsters: biology, management, aquaculture and fisheries. Oxford, Blackwell.

Pinheiro, M.A.A. and Taddei, F.G. 2005. Crescimento do caranguejo de água doce, Dilocarcinus pagei Stimpson (Crustacea, Brachyura, Trichodactylidae). Revista brasileira de Zoologia, 22: 522-528.

Pinheiro, M.A.A.; Fiscarelli, A.G. and Hattori, G.Y. 2005. Growth of the mangrove crab Ucides cordatus (Brachyura, Ocypodidae). Journal of Crustacean Biology, 25: 293-301.

Pratten, D.J. 1980. Growth in the crayfish Austropotamobius pallipes (Crustacea: Astacidae). Freshwater Biology, 10: 401-412.

Rademacher, M. and Mengedoht, O. 2011. Krabben-Fibel. Ettlingen, Dähne-Verlag, 95p.

Ragonese, S.; Vitale, S.; Dimech, M. and De Santi, A. 2012. Growth discontinuity in males of the deep-water giant red shrimp Aristaeomorpha foliacea in the Mediterranean Sea. Marine Ecology, 33: 386-392.

Rahman, M. and Ohtomi, J. 2018. Recruitment, growth patterns, and longevity of the deep-water velvet shrimp Metapenaeopsis sibogae (De Man, 1907) (Decapoda: Dendrobranchiata: Penaeidae). Journal of Crustacean Biology, 38: 552-562.

Rajasree, R.; Harikrishnan, M. and Madhusoodana Kurup, B. 2011. Stock characteristics and population dynamics of Heterocarpus woodmasoni Alcock. Journal of the Marine Biological Association of India, 53: 101-107.

Roa, R. and Ernst, B. 1996. Age structure, annual growth, and variance of size-at-age of the shrimp Heterocarpus reedi. Marine Ecology Progress Series, 137: 59-70.

Rocha, S.S.; Shimizu, R.M. and Bueno, S.L.S. 2010. Reproductive biology in females of Aegla strinatii (Decapoda: Anomura: Aeglidae). Journal of Crustacean Biology, 30: 589-596.

Rossetti, I.; Sartor, P.; Francesconi, B.; Mori, M. and Belcari, P. 2006. Biological aspects of Medorippe lanata (Linnaeus, 1767) (Brachyura: Dorippidae) from the eastern Ligurian Sea (western Mediterranean). Hydrobiologia, 557: 21.

Rostant, L.V.; Alkins-Koo, M. and Maitland, D.P. 2008. Growth and maturity in the manicou crab Eudaniela garmani (Brachyura: Pseudothelphusidae) from Trinidad, West Indies. Journal of Crustacean Biology, 28: 485-493. 
Rugolo, L.J.; Knotts, K.S.; Lange, A.M. and Crecco, V.A. 1998. Stock assessment of Chesapeake Bay blue crab (Callinectes sapidus Rathbun). Journal of Shellfish Research, 17: 905-930.

Sadakata, T. 1999. On the growth of northern shrimp Pandalus eous in the waters off Noto Peninsula, the Sea of Japan. Nippon Suisan Gakkaishi, 65: 1010-1022. (in Japanese)

Sadykova, D.; Skurdal, J.; Hessen, D.O. and Schweder, T. 2011. Saving the largest makes a difference: exploring effects of harvest regulations by model simulations for noble crayfish, Astacus astacus. Fisheries Management and Ecology, 18: 307313.

Sainte-Marie, B.; Bérubé, I.; Brillon, S. and Hazel, F. 2006. Observations on the growth of the sculptured shrimp Sclerocrangon boreas (Decapoda: Caridea). Journal of Crustacean Biology, 26: 55-62.

Sarda, F. and Demestre, M. 1987. Estudio biológico de la gamba Aristeus antennatus (Risso, 1816) en el Mar Catalàn (NE de España). Investigación Pesquera, 51, Suplemento 1: 213-232.

Sastre, M.P. 1991. Sex-specific growth and survival in the mole crab Emerita portoricensis (Schmitt). Journal of Crustacean Biology, 11: 103-112.

Scalici, M. and Gherardi, F. 2007. Structure and dynamics of an invasive population of the red swamp crayfish (Procambarus clarkii) in a Mediterranean wetland. Hydrobiologia, 583: 309-319.

Scalici, M.; Belluscio, A. and Gibertini, G. 2008a. Understanding the population structure and dynamics in threatened crayfish. Journal of Zoology, 275: 160-171.

Scalici, M.; Macale, D.; Schiavone, F.; Gherardi, F. and Gibertini, G. 2008b. Effect of urban isolation on the dynamics of river crabs. Fundamental and Applied Limnology, 172: 167-174.

Sheehy, M.R.J. 1992. Lipofuscin age-pigment accumulation in the brains of ageing field- and laboratory-reared crayfish Cherax quadricarinatus (von Martens) (Decapoda: Parastacidae). Journal of Experimental Marine Biology and Ecology, 161: 79-89.

Sheehy, M.R.J. 2002. Role of environmental temperature in aging and longevity: insights from neurolipofuscin. Archives of Gerontology and Geriatrics, 34: 287-310.

Sheehy, M.R.J. and Prior, A.E. 2008. Progress on an old question for stock assessment of the edible crab Cancer pagurus. Marine Ecology Progress Series, 353: 191-202.

Sheehy, M.; Cameron, E.; Marsden, G. and McGrath, J. 1995a. Age structure of female giant tiger prawns Penaeus monodon as indicated by neuronal lipofuscin concentration. Marine Ecology Progress Series, 117: 59-63.

Sheehy, M.R.J.; Greenwood, J.G. and Fielder, D.R. 1995b. Lipofuscin as a record of "rate of living" in an aquatic poikilotherm. Journal of Gerontology A, Biological Sciences, 50: B327-336.

Sheehy, M.R.J.; Bannister, R.C.A.; Wickins, J.F. and Shelton, P.M.J. 1999. New perspectives on the growth and longevity of the European lobster (Homarus gammarus). Canadian Journal of Fisheries and Aquatic Sciences, 56: 1904-1915.

Sheridan, M. and O'Connor, I. 2018. Evidence of complete gastric mill ossicle loss at ecdysis in the European green crab Carcinus maenas (Linnaeus, 1758) (Decapoda: Brachyura: Carcinidae). Journal of Crustacean Biology, 38: 435-442.
Shinozaki-Mendes, R.A.; Silva, A.A.G.; Mendes, P.P. and Lessa, R. 2012. Age and growth of Callinectes danae (Brachyura: Portunidae) in a tropical region. Journal of Crustacean Biology, 32: 906-915.

Silva, E.F.; Calazans, N.; Nolé, L.; Viana, A.; Soares, R.; Peixoto, S. and Frédou, F.L. 2015. Population dynamics of the pink shrimp Farfantepenaeus subtilis (Pérez-Farfante, 1967) in northeastern Brazil. Journal of Crustacean Biology, 35: 132139.

Silva-Gonçalves, R.; Bond-Buckup, G. and Buckup, L. 2009. Crescimento de Aegla itacolomiensis (Crustacea, Decapoda) em um arroio da Mata Atlântica no sul do Brasil. Iheringia, Série Zoologia, 99: 397-402.

Skurdal, J. and Taugbøl, T. 2002. Astacus. p. 467-510. In: D.M. Holdich (ed), Biology of freshwater crayfish. Oxford, Blackwell.

Sokholov, V. I. 2002. On biology of Pandalus borealis (Decapoda, Pandalidae) from the Western Bering Sea. Zoologichesky Zhurnal, 81: 154-164. (in Russian)

Soong, K. 1997. Some life history observations on the pea crab, Pinnotheres tsingtaoensis, symbiotic with the bivalve mollusk, Sanguinolaria acuta. Crustaceana, 70: 855-866.

Species Bank. 2019. Coenobita variabilis. Australian Government, Department of the Environment and Energy. Available on http://www.environment.gov.au/cgi-bin/species-bank/ sbank-treatment2.pl?id=81631. Accessed on 5 March 2019.

Spivak, E.D.; Arévalo, E.; Cuesta, J.A. and González-Gordillo, J.I. 2010. Population structure and reproductive biology of the stone crab Xantho poressa (Crustacea: Decapoda: Xanthidae) in the 'Corrales de Rota' (south-western Spain), a humanmodified intertidal fishing area. Journal of the Marine Biological Association of the United Kingdom, 90: 323-334.

Streever, W.J. 1996. Energy economy hypothesis and the troglobitic crayfish Procambarus erythrops in Sim's Sink Cave, Florida. American Midland Naturalist, 135: 357-366.

Streissl, F. and Hödl, W. 2002. Growth, morphometrics, size at maturity, sexual dimorphism and condition index of Austropotamobius torrentium Schrank. Hydrobiologia, 477: 201-208.

Taddei, F.G. and Herrera, D.R. 2010. Crescimento do caranguejo Dilocarcinus pagei Stimpson, 1861 (Crustacea, Brachyura, Trichodactylidae) na Represa Barra Mansa, Mendonça, SP. Boletim do Instituto de Pesca São Paulo, 36: 99-110.

Taylor, C.A. 2003. Conservation assessment for a crayfish (Orconectes placidus). Milwaukee, USDA Forest Service, Eastern Region, 11p.

Thorne, B.L.; Breisch, N.L. and Haverty, M.I. 2002. Longevity of kings and queens and first time of production of fertile progeny in dampwood termite (Isoptera; Termopsidae; Zootermopsis) colonies with different reproductive structures. Journal of Animal Ecology, 71: 1030-1041.

Thurman, C.L.; Faria, S.C. and McNamara, J.C. 2013. The distribution of fiddler crabs ( $U c a$ ) along the coast of Brazil: implications for biogeography of the western Atlantic Ocean. Marine Biodiversity Records, 6: e1.

Turra, A. and Leite, F.P.P. 2000. Population biology and growth of three sympatric species of intertidal hermit crabs in southeastern Brazil. Journal of the Marine Biological Association of the United Kingdom, 80: 1061-1069. 
U.S. Fish and Wildlife Service. 2010. Kentucky cave shrimp (Palaemonias ganteri). 5-year review: summary and evaluation. Frankfort, U.S. Fish and Wildlife Service, 16p.

U.S. Fish and Wildlife Service. 2015. Spiny-cheek crayfish (Orconectes limosus). Ecological risk screening summary. U.S. Fish and Wildlife Service, 12p.

Valenti, W.C.; de Mello, J.T.C. and Lobão, V.L. 1994. Maturation and growth curves of Macrobrachium carcinus (Linnaeus) (Crustacea, Decapoda, Palaemonidae) from Ribeira de Iguape river, southern Brazil. Revista brasileira de Zoologia, 11: 649-658.

Van den Brink, A.M. 2006. The reproductive ecology and biology of the pill-box crab: Halicarcinus cookii Filhol, 1885 (Brachyura: Hymenosomatidae). Christchurch, University of Canterbury, M.Sc. Thesis. 156p. [Unpublished].

Vázquez, M.G.; Bass, C.C. and Spivak, E.D. 2012. Life history traits of the invasive estuarine shrimp Palaemon macrodactylus (Caridea: Palaemonidae) in a marine environment (Mar del Plata, Argentina). Scientia Marina, 76: 507-516.

Veloso, V.G. and Cardoso, R.S. 1999. Population biology of the mole crab Emerita brasiliensis (Decapoda: Hippidae) at Fora Beach, Brazil. Journal of Crustacean Biology, 19: 147-153.

Venarsky, M.P.; Huryn, A.D.; Benstead, J.P. 2012. Re-examining extreme longevity of the cave crayfish Orconectes australis using new mark-recapture data: a lesson on the limitations of iterative size-at-age models. Freshwater Biology, 57: 14711481.

Vinuesa, J.H. and Ferrari, L. 2008. Reproduction of Halicarcinus planatus (Crustacea, Decapoda, Hymenosomatidae) in the Deseado River estuary, southwestern Atlantic Ocean. Marine Biology, 154: 345-351.

Viswanathan, C.; Pravinkumar, M.; Suresh, T.V.; Elumalai, V. and Raffi, S.M. 2016. Carapace width-weight relationship, age, growth and longevity of the mud crab Scylla olivacea (Herbst, 1796) in the Pichavaram mangroves, south-east India. Journal of the Marine Biological Association of the United Kingdom, 96: 1379-1386.

Vitale, S.; Cannizzaro, L.; Lumare, L. and Mazzola, S. 2010. Population parameters of Melicertus kerathurus (Decapoda, Penaeidae) in southwest Sicilian shallow waters (Mediterranean Sea) using length-frequency analysis. Crustaceana, 83: 997-1007.

Vogt, G. 2010. Suitability of the clonal marbled crayfish for biogerontological research: a review and perspective, with remarks on some further crustaceans. Biogerontology, 11: 643-669.

Vogt, G. 2012. Ageing and longevity in the Decapoda (Crustacea): a review. Zoologischer Anzeiger, 251: 1-25.

Vogt, G. 2014. Life span, early life stage protection, mortality and senescence in freshwater Decapoda. p. 17-51. In: D.C.J. Yeo; N. Cumberlidge and S. Klaus (eds), Advances in freshwater decapod systematics and biology. Crustaceana Monographs 19. Leiden, Brill.

Vogt, G. 2018. Growing old: aging in Crustacea. p. 179-202. In: G. Wellborn and M. Thiel (eds), The natural history of the Crustacea. Volume 5: Life histories. New York, Oxford University Press.

Vorstman, A.G. 1955. Investigations on the life cycle of Atyaephyra desmaresti (Mill.). Verhandlungen der Internationalen Vereinigung für Limnologie, 12: 469-477.

Walls, J.G. 2009. Crawfishes of Louisiana. Baton Rouge, Louisiana State University Press, 241p.

Wendler, F.; Biss, R. and Chucholl, C. 2015. Population ecology of endangered white-clawed crayfish (Austropotamobius pallipes s. str.) in a small rhithral river in Germany. Knowledge and Management of Aquatic Ecosystems, 416: 24.

Weşławski, J.M. 1987. Distribution of Decapoda (Crustacea) in South Spitsbergen coastal waters with remarks on their ecology and breeding biology. Polish Polar Research, 8: 121-134.

Whitmore, N. and Huryn, A.D. 1999. Life history and production of Paranephrops zealandicus in a forest stream, with comments about the sustainable harvest of a freshwater crayfish. Freshwater Biology, 42: 467-478.

Wirbellosen Datenbank. 2019a. Caridina multidentata Amanogarnele. Available at https://www.wirbellose.de/ artendatenbank/zwerggarnelen/1704-caridina-multidentataamanogarnele. Accessed on 14 March 2019.

Wirbellosen Datenbank. 2019b. Palaemonetes antennarius Europäische Süsswassergarnele. Available at https://www. wirbellose.de/artendatenbank/grossarmgarnelen/1580palaemonetes-antennarius-europaeische-suesswassergarnele. Accessed on 15 March 2019.

Wirbellosen Datenbank. 2019c. Cambarellus patzcuarensis Oranger Zwergkrebs. Available at https:/ / www.wirbellose.de/ artendatenbank/krebse/1783-cambarellus-patzcuarensis-sporange-oranger-zwergkrebs-cpo. Accessed on March 15, 2019.

Wirbellosen Datenbank. 2019d. Procambarus alleni sp. blau Florida-Krebs. Available at https://www.wirbellose.de/ artendatenbank/krebse/1868-procambarus-alleni-sp-blauflorida-krebs. Accessed on 21 March 2019.

Wolcott, T.G. 1988. Ecology. p. 55-96. In: W.W. Burggren and B.R. McMahon (eds), Biology of the land crabs. Cambridge, Press Syndicate of the University of Cambridge.

Wolff, T. 1978. Maximum size of lobsters (Homarus) (Decapoda, Nephropidae). Crustaceana, 34: 1-14.

Yam, R.S.W. and Dudgeon, D. 2005. Inter- and intraspecific differences in the life history and growth of Caridina spp. (Decapoda: Atyidae) in Hong Kong streams. Freshwater Biology, 50: 2114-2128.

Yamaguchi, T.2002. Survival rate and age estimation of the fiddler crab, Uca lactea (De Haan, 1835) (Decapoda, Brachyura, Ocypodidae). Crustaceana, 75: 993-1014. 